\title{
Leptin signaling and circuits in puberty and fertility
}

\author{
Carol F. Elias · Darshana Purohit
}

Received: 24 May 2012/Revised: 5 July 2012/Accepted: 9 July 2012/Published online: 2 August 2012

(C) The Author(s) 2012. This article is published with open access at Springerlink.com

\begin{abstract}
Leptin is an adipocyte-derived hormone involved in a myriad of physiological process, including the control of energy balance and several neuroendocrine axes. Leptin-deficient mice and humans are obese, diabetic, and display a series of neuroendocrine and autonomic abnormalities. These individuals are infertile due to a lack of appropriate pubertal development and inadequate synthesis and secretion of gonadotropins and gonadal steroids. Leptin receptors are expressed in many organs and tissues, including those related to the control of reproductive physiology (e.g., the hypothalamus, pituitary gland, and gonads). In the last decade, it has become clear that leptin receptors located in the brain are major players in most leptin actions, including reproduction. Moreover, the recent development of molecular techniques for brain mapping and the use of genetically modified mouse models have generated crucial new findings for understanding leptin physiology and the metabolic influences on reproductive health. In the present review, we will highlight the new advances in the field, discuss the apparent contradictions, and underline the relevance of this complex physiological system to human health. We will focus our review on the hypothalamic circuitry and potential signaling pathways relevant to leptin's effects in reproductive control, which
\end{abstract}

\section{F. Elias $(\square)$}

Division of Hypothalamic Research, Department of Internal Medicine, University of Texas Southwestern Medical Center, 5323 Harry Hines Blvd, Y6-220B, Dallas, TX 75390-9077, USA

e-mail: carol.elias@utsouthwestern.edu

D. Purohit

Division of Endocrinology and Metabolism, Department of Internal Medicine, University of Texas Southwestern Medical Center, Dallas, TX, USA have been identified with the use of cutting-edge technologies of molecular mapping and conditional knockouts.

Keywords Hypothalamus - Energy balance - HPG axis · Reproduction $\cdot$ Neuroendocrine regulation

\section{Introduction}

Leptin is a hormone primarily synthesized and secreted by the white adipose tissue [362]. It is encoded by the Lep/LEP gene (previously named $o b$ gene, for obese) and circulates in the plasma in free and bound forms. Leptin receptors, encoded by Lepr/LEPR gene are found in six isoforms expressed in a variety of organs and cell types $[4,75,124,238,243,318,361]$. In the last 15 years or so, leptin's crucial role in multiple endocrine, metabolic and autonomic functions has been unraveled. In the present review, we will highlight the role of leptin in the control of the reproductive neuroendocrine axis. Innumerous studies have described a critical role for leptin in gonadal function, uterine physiology, pregnancy, and implantation, which will not be explored in this review. For discussions on these issues, we recommend consulting the following articles [40, 51, 130, 150, 166, 207, 271, 321]. Herein, we will give special attention to recent advances in the identification of key hypothalamic sites and signaling pathways relevant for leptin's action in reproductive control.

\section{Leptin action as a signal of energy sufficiency}

Under physiologic conditions, circulating levels of leptin are highly correlated with stored adipocyte mass [83, 215, 362]. Leptin levels fall quickly during starvation, in 
parallel with the stereotypical response of various neuroendocrine systems and, therefore, fluctuations in the levels of leptin are viewed as a key metabolic cue for the neuroendocrine adaptations that occur during negative energy balance $[6,61,68,124]$. Falling leptin levels signal energy insufficiency, inducing counter-regulatory responses to preserve or accumulate energy. Increases in appetite and motivation for food search, decreases in thermogenesis and locomotor activity, inhibition of the thyroid axis and activation of the hypothalamic-pituitary-adrenal axis are examples of critical adaptive responses [2]. Additionally, likely due to the high energetic costs of reproductive processes such as pregnancy and lactation, states of negative energy balance rapidly inhibit the reproductive function. Fasting rodents and primates exhibit decreases in sex steroids, pulsatile luteinizing hormone $(\mathrm{LH})$ secretion and fertility [52-54, 215, 221, 258, 339]. Studies from several laboratories, using different species and paradigms, have demonstrated that leptin administration blunts the fastinginduced suppression of $\mathrm{LH}$ secretion, restores female cyclicity and improves fertility [5, 140]. In mice, $48 \mathrm{~h}$ of food deprivation led to decreased LH levels and longer estrous cycles. Chronic leptin administration sustained elevated LH secretion and precluded estrus delay [5]. Likewise, chronic administration of leptin prevented the reduction of LH pulse frequency in fasted female rats, and maintenance of steady physiologic levels of leptin allowed a preovulatory LH surge in fasted rats [245, 337] (but see also [324]). Acute leptin administration to food-deprived male or female rats induced a rapid increase in $\mathrm{LH}$ pulse frequency and amplitude [98, 140], and intracerebroventricular administration of leptin antiserum disrupted cyclicity and LH secretion in fed rats [60].

Similar effects of leptin are less clear in non-human primates as only very high doses of leptin can sustain LH levels in fasted monkeys [122, 191, 192, 220]. Moreover, seasonal breeders (e.g., sheep and hamsters) appear to have evolved divergent strategies to assure reproductive success, favoring photoperiodic cues over metabolic signals. For discussion of species differences and contradictions please see $[262,288]$. However, as a valuable proof-of-principle, leptin treatment increased pulse frequency and mean levels of LH, estradiol, ovarian volume and number of dominant follicles in women with hypothalamic amenorrhea resulting from extreme exercise and weight loss [68, 206, 234, $335,341]$. Therefore, despite species differences and controversies in the field, it is now well-accepted that leptin is a key metabolic cue that signals energy sufficiency to control adequacy and timing of reproductive function.

Recently, a series of compounds with the ability of blocking leptin action were produced, including leptin antagonists and antibodies against the leptin binding domain of LepR [120, 254, 303]. With these tools, temporary/reversible blockade of leptin action became feasible and, therefore, the use of these compounds is expected to contribute to our understanding of leptin physiology. For example, treatment of rats with leptin antagonist during early postnatal life impaired the appropriate development of several organs, including ovaries with marked decrease of primordial follicles [12]. This study highlights a previously unrecognized role of leptin in postnatal maturation of reproductive organs.

\section{Effects of leptin deficiency in the reproductive neuroendocrine axis}

The genetic mutation causing leptin deficiency was first identified in C57BL/6 mice (named $o b / o b$, for obese) at Jackson Laboratories [165]. The mutation was later defined as autosomal recessive, and homozygotes are morbidly obese due to hyperphagia and decreased energy expenditure and display multiple neuroendocrine abnormalities [79, 362]. Leptin-deficient mice of both sexes are infertile, but some degree of reproductive capability has been described in young ob/ob males [194]. At prepubertal stages, the reproductive organs of $o b / o b$ mice are indistinguishable from wild-type, but neither males nor females attain sexual maturation. Proper sexual development and fertility is only achieved if leptin is provided [21, 70, 239]. The infertility phenotype observed in leptin-deficient mice is dependent on genetic background, as obese $o b / o b$ mice crossed onto a BALB/cJ strain have improved fertility. The effect of the so called, but yet unidentified, genetic modifiers appears to be sexually dimorphic. Males from the F2 generation are partially fertile, whereas females only show improved fertility after ten generations of backcrossing of the $o b$ mutation onto the $\mathrm{BALB} / \mathrm{cJ}$ genetic background [266].

The reproductive organs of leptin-deficient male and female mice (in C57BL/6 background) display a series of morphological and biochemical abnormalities. The weights of ventral prostate and testes are decreased while the reported weights of the seminal vesicles are variable [239, 317]. The seminiferous tubules contain fewer sperm and the Leydig cells are reduced in size [239]. The uterus is immature and ovaries have a comparable number of follicles to wild-type mice at initial stages, but no mature follicles or corpora lutea were detected [21]. The uterus and ovaries respond adequately to exogenous estradiol and gonadotropins [103, 193]. When transplanted to wild-type females, ovaries of $o b / o b$ mice produce sex steroids and viable oocytes, and gametogenesis may be restored by exogenous administration of gonadotropins [24, 161].

Leptin-deficient male and female mice show reduced pituitary content of luteinizing hormone (LH) and 
increased pituitary content of follicle stimulating hormone (FSH) [24, 317]. However, circulating levels of LH and FSH are decreased in both male and female $o b / o b$ mice. Increased gonadotropin secretion can be induced by castration, although at a lower magnitude compared to the wild-type [193, 317]. Notably, ob/ob mice are highly sensitive to the suppressive effects of sex steroids on gonadotropin secretion, consistent with a prepubertal condition of high negative feedback restraint [317]. Gonadotropes of $o b / o b$ mice respond adequately to gonadotropin releasing hormone $(\mathrm{GnRH})$ challenges, and $o b / o b$ female mice can ovulate and become fertile if levels of gonadotropins and sex steroids are maintained at physiological ranges [161]. Interestingly, compared to the wildtype, higher GnRH content is observed in the hypothalamus of adult $o b / o b$ mice [24]. These findings indicate that leptin-deficient mice have adequate development and functioning of gonadotropes and gonads but deficient GnRH secretion at the expected time of puberty onset. Consistent with this concept, in vitro and in vivo studies have determined that leptin acts primarily in the brain by stimulating GnRH secretion [198, 199, 257, 347, 358].

\section{Leptin signaling deficiency in humans}

In humans, leptin signaling deficiency caused by genetic mutations is a rare condition. In general, two forms of congenital leptin signaling deficiency have been identified: mutation in leptin ( $L E P)$ gene and mutation in leptin receptor $(L E P R)$ gene. Both comprise rare causes of monogenic obesity and infertility. Individual heterozygotes for $L E P$ or $L E P R$ genes mutation undergo puberty and show apparently normal reproductive life. Therefore, only one functional copy of $L E P$ or $L E P R$ genes is required for the normal progression of sexual maturation and fertility. Twenty-nine cases of loss-of-function of LEP gene and 20 cases of mutation impairing LEPR signaling have been reported in the literature $[77,118,119,123,129,205,227$, 228, 259]. Affected individuals are usually born with normal birth weights but rapidly gain weight in their first few months of life. They exhibit hyperphagia with aggressive behavior if food is denied, and become morbidly obese. Failure of pubertal growth spurt and lack of secondary sexual characteristics is usually observed [117]. However, one affected Turkish female with LEP gene mutation began to have menses after a delay of 20 years. In addition, three women with $L E P R$ mutations had irregular menses starting in their third to fourth decade of life, and sex hormones were consistent with their age [255]. Recombinant leptin therapy to leptin-deficient subjects has restored the gonatropic axis, induce puberty, correct menstrual irregularities, increase height and reduce relative fat mass [116]. No therapy has been described for subjects with $L E P R$ mutation.

The role of leptin deficiency in constitutional delay in growth and puberty (CDGP) has also been investigated. Subjects with CDGP have lower leptin levels compared to normal controls [31, 137]. They are usually underweight for their height exhibiting decreased adipose tissue mass and low circulating levels of leptin and, therefore, the delayed puberty onset has been interpreted as a consequence of low leptin production [107]. A missense variant in LEP gene was identified in one individual with CDGP [241]. The sequence variant was also detected in his mother that exhibited similar features of decreased fat mass and delayed sexual maturation. Interestingly, this sequence variant was associated with delayed puberty in the context of decreased body mass index (BMI) rather than obesity. Because of this unexpected outcome, further investigation is necessary to determine if pubertal delay is directly associated with deficient leptin signaling.

\section{Leptin as a permissive factor for the onset of puberty}

Many aspects of the reproductive physiology are energetically demanding (e.g., territoriality for males or pregnancy and lactation for females) and, therefore, the individual nutritional condition is a key factor in the onset of puberty [91, 108, 272, 322]. Seminal studies by Kennedy and Mitra [182] showed that the time of puberty initiation in rats is correlated with body size, not chronological age. Subsequently, a series of epidemiological studies in humans proposed that a critical amount of body fat is required for proper sexual maturation [126, 127]. Following its discovery as an adipocyte-derived hormone in 1994, leptin was readily recognized as the potential link between energy stores (adiposity) and the progression of puberty.

Due to the infertility of the $o b / o b$ mice and the complete rescue of fertility following leptin administration, leptin was initially hypothesized to be the key signal for the onset of puberty. However, it soon became clear that leptin is rather a permissive factor that is required, but not sufficient, for normal sexual maturation. In this respect, a critical evaluation of some apparent controversies is necessary. Different laboratories have reported dissimilar results on the ability of exogenous leptin to advance the onset of puberty in rodents $[3,9,72]$. Leptin administration at low concentrations, which are insufficient to alter metabolism, in female mice induced an advance in the onset of puberty [3]. In prepubertal female rats, leptin increased the secretion of gonadotropin and the expression of ovarian steroidogenesis enzymes and advanced puberty [9]. In another study, leptin administration was linked to decreased food consumption and did not advance the age at 
puberty onset. However, pair-fed mice used as controls in this paradigm showed delayed puberty onset, suggesting that leptin administration prevented the delayed pubertal development caused by the negative energy balance [ 72 , 73]. This finding is in agreement with studies showing that maintenance of adequate leptin levels prevents pubertal delay in conditions of negative energy balance [143]. In this context, leptin also functions as a metabolic signal of energy sufficiency, as previously discussed. Low leptin levels induced by a negative energy balance halt sexual maturation, which can be restored by leptin administration.

An additional argument in favor of a role for leptin in puberty initiation would be the occurrence of changes in leptin levels or signaling during the pubertal transition. While still controversial, nocturnal increases in leptin secretion before puberty have been observed in both rats and primates [244, 314]. Moreover, mice overexpressing leptin (transgenic skinny mice) showed early appearance of vaginal opening followed by uterine and ovarian maturation, suggestive of accelerated activity of the hypothalamuspituitary-gonads (HPG) axis [360]. The skinny female mice also showed an advance in reproductive senescence, indicating that in addition to the advance in the onset of puberty, hyperleptinemia may promote reproductive failure at early ages. Whether this represents a physiological correlation to the dysfunctional activity of the HPG axis observed in obese patients still needs to be demonstrated. Along the same lines, recent studies have suggested that the hyperleptinemia observed in young obesity or overnutrition may be the cause of reported advances in the age of puberty onset $[33,62,108$, 322]. For more details and discussion, we recommend consulting recently published articles focused on this specific issue $[7,34,49,104,108,171]$.

\section{Leptin signaling and the reproductive function}

The LepR is a member of the class 1 cytokine receptor family and is found in six isoforms, all derived from splice variants of the LEPR/Lepr gene [75, 200, 318]. Of the six isoforms, only the LepR long form (302 amino acids intracellular domain) contains a Box 3 motif, which enables the activation of the Janus kinase/signal transducer and activator of transcription (JAK/STAT) signaling pathway [36, 243, 354]. Binding of JAK2 to STAT3 leads to its phosphorylation at Tyr1138 and translocation to the nucleus where it functions as a transcription factor [19, 240]. Thus, the long-form of leptin receptor (a.k.a. LepRb) is recognized as the physiologically relevant signaling isoform. Consistent with this concept, loss-of-function mutations of LEPR/Lepr long-form in humans and mice ( $d b / d b$ mice) cause metabolic and reproductive phenotypes remarkably similar to leptin-deficient subjects [77, 79].
The selective deletion of leptin-induced STAT3 signaling in cells that express LepR $\left(\mathrm{LRb}^{\mathrm{S} 1138} s / s\right.$ mice) recapitulates most of the $d b / d b$ metabolic phenotype, producing hyperphagia, high adiposity and disruption of the melanocortin circuitry in both males and females [23]. However, these mice show improved glucose homeostasis and increased body length compared to $d b / d b$ mice, and while $d b / d b$ mice are infertile, a relatively high proportion $(40 \%)$ of $\mathrm{LRb}^{\mathrm{S} 1138} s / s$ female mice are fertile [23]. All $\mathrm{LRb}^{\mathrm{S} 1138} s / s$ females displayed estrous cyclicity, development of reproductive organs and ovarian signs of ovulation, supporting the concept that hypothalamic control of reproduction by leptin is mediated by a STAT3-independent signaling pathway [23]. Subsequent studies have reported a seemingly contrasting result. Deletion of STAT3 signaling (STAT3 ${ }^{\mathrm{N}-1-}$ ) from the brain (Nestin-Cre mouse model) resulted in hyperphagic obesity, and high plasma corticosterone, glucose and insulin levels, similar to $o b / o b$ and $d b / d b$ mice [134]. Males and females were infertile with deficient development of the reproductive organs. In the attempt to evaluate the contribution of STAT3 signaling pathways to the acute effects of leptin, another group used stereotaxic injection to deliver a cell-permeable phosphopeptide inhibitor of STAT3 phosphorylation into the mediobasal hypothalamus. Females with acute blockade of STAT3 in the ventromedial hypothalamus did not show leptin-induced LH secretion during fasting, indicating that STAT3 expression in the mediobasal hypothalamus is required for the acute effects of leptin on fasting-induced suppression of LH secretion [46]. In this study, the authors also used genetically modified mouse models to demonstrate the requirement of STAT3 signaling for the acute effects of leptin on food intake and glucose metabolism [46]. Although these mouse studies have generated some controversies concerning the role of leptininduced phosphorylation of STAT3 in reproductive function, it is important to stress that STAT3 signaling pathways is not unique to leptin response. STAT3 is a common transcription factor recruited by several cytokines including ciliary neurotrophic factor (CNTF) and interleukin 6 (IL6) [38]. Moreover, and of particular relevance to our topic, estrogen appears to also induce phosphorylation of STAT3 in mediobasal hypothalamic neurons [133]. Deletion of STAT3 from all cells in the brain or stereotaxic delivery of STAT3 inhibitor into the mediobasal hypothalamus may block a critical pathway for the control of reproductive physiology unrelated to leptin signaling. Endogenous and selective blockade of leptin-induced STAT3 rendered a mouse model with metabolic features similar to leptin-signaling deficiency but with improved fertility, indicating that the full effect of leptin on reproduction requires the recruitment of a STAT3-independent signaling pathway. 
Several studies support the hypothesis that leptin also engages the phosphoinositide 3-kinase (PI3K) signaling pathways to exert its effects [243, 250, 352, 363]. For example, in hypothalamic slices, leptin hyperpolarizes a subset of arcuate nucleus neurons via activation of an ATP sensitive potassium channel, resulting in reduced firing rates $[309,310]$. This effect is fully blocked by PI3K inhibitors [250, 345]. Likewise, the leptin-mediated depolarizing effect on proopiomelanocortin (POMC) neurons is dependent on PI3K signaling and administration of PI3K inhibitors blunted the ability of ICV leptin to reduce food intake [156, 250, 363]. In addition, blockade of PI3K signaling precluded the ability of hypothalamic leptin administration to inhibit white adipose tissue lipogenesis [45].

The mechanism by which leptin triggers PI3K activity is thought to be via phosphorylation of insulin receptor substrate-2 (IRS-2) [47, 249]. As the name implies, IRSs are also implicated in insulin signaling [342], but the extent of overlap between leptin and insulin cellular responses in different organs and tissue is still unsettled. IRS-2 is expressed in hypothalamic sites responsive to leptin and related to metabolic control, including the arcuate nucleus and the ventromedial nucleus of the hypothalamus [256]. Global deletion of IRS-2 (IRS-2 $2^{-1-}$ ) in mice cause metabolic dysfunction and female infertility [48]. IRS-2 $2^{-/-}$ female mice failed to cycle and ovulate, had decreased levels of sex hormones and deficient ovarian development. Interestingly, recent studies have shown that mice with inactivation of IRS-2 specifically in LepR neurons are fertile, but whether these mice display regular puberty onset, cyclicity, sex hormone levels in response to metabolic challenges or advanced or delayed reproductive senescence has not been reported [279].

Multiple forms of PI3Ks exist. The class 1a enzymes are heterodimers consisted of one regulatory and one catalytic subunit. There are typically five regulatory subunits, collectively referred to as $\mathrm{p} 85 \mathrm{~s}$, and the catalytic subunits are comprised of three variants referred to as p110s [58, 331]. Activation occurs when $\mathrm{p} 85$ binds to IRS and localizes the catalytic activity/subunit to the cell membrane, where PI3K catalyzes the phosphorylation of PIP2 to PIP3 that, in turn, recruits and activates downstream targets. The PI3K catalytic subunits $\mathrm{p} 110 \alpha$ and $\mathrm{p} 110 \beta$ are ubiquitously expressed, and global deletion of either one is embryonically lethal [29, 30, 69, 159]. However, mice carrying a knock-in mutation causing a $50 \%$ loss-of-function of $\mathrm{p} 110 \alpha$ activity are viable, but displayed suppressed IRS-2 signaling and, thereby, decreased responsiveness to insulin and leptin, hyperphagia, glucose intolerance and increased adiposity [125]. Both catalytic subunits are coexpressed in hypothalamic neurons, which express LepR [345]. Selective deletion of these subunits from LepR-expressing neurons precludes leptin-induced changes in cellular activity [8, 345]. However, whether the lack of leptin-induced PI3K signaling results in reproductive deficits has not been reported.

Another signaling pathway potentially recruited by leptin is the mammalian target of rapamycin (mTOR) [87]. The mTOR is a highly conserved serine-threonine kinase downstream of the PI3K-Akt pathway, which is involved in multiple physiologic regulations. Of importance to this review is its critical function in the control of growth and development via the integration of signals from nutrients and circulating factors $[160,196]$. The availability of nutrients (amino acid L-leucine) and adequate levels of adenosine-triphosphate (ATP) activate mTOR that, in turn, induces protein synthesis $[147,160,287]$. Therefore, mTOR is recognized as a sensor of energy availability in cellular growth and development. Mutation in the gene encoding Mtor in mice is embryonically lethal, whereas increased activity of mTOR induces metabolic dysfunctions including obesity and diabetes [131, 151, 160, 237]. High levels of constitutive mTOR activity down-regulate insulin and growth factor signaling by decreasing insulin receptor substrate (IRS1/2) expression and protein stability [299, 327]. In agreement, the activation of mTOR pathway is elevated in the liver and in the skeletal muscle of insulinresistant obese rats maintained on a high-fat diet, whereas absence of a downstream mTOR target, the ribosomal S6 kinase (S6K), protects against diet-induced obesity and enhances insulin sensitivity in mice [183, 328]. Following this line, leptin administration to rodents induced phosphorylation of downstream targets of mTOR (S6K1), and blockade of mTOR by rapamycin precluded leptin-induced phosphorylation of S6K1 and the effects of leptin to reduce food intake [87].

A role for mTOR in the neuroendocrine reproductive axis of the female rats was reported [273, 274]. Activation of the mTOR pathway by acute administration of L-leucine increased LH levels in prepubertal mice, whereas L-leucine chronic treatment resulted in no changes in puberty onset. Likewise, L-leucine administration slightly increased LH levels in caloric restricted prepubertal female rats, but did not correct the delayed onset of puberty typical of this experimental model. On the other hand, blockade of mTOR by central administration of rapamycin delayed puberty and blunted leptin's effects in promoting pubertal development of food-restricted female rats [273, 274]. It will be important to define whether this effect is directly associated with leptin signaling or with a general blockade of a crucial factor of adequate nutrition and energy availability required for reproductive function.

Recent studies have also suggested a role for Crtc1 (cAMP-responsive element-binding protein regulated transcription coactivator-1) linking energy balance and 
reproduction [10]. Crtc1 is a cytoplasmic coactivator highly expressed in the brain. It translocates to the nucleus following dephosphorylation induced by cAMP or calcium activation [35, 295]. Two independent groups have reported that mice with a loss-of-function mutation in the Crtcl gene develop obesity [10, 42]. However, infertility was only observed in one mutant mouse line [10]. Females from the mutant line generated by Alterejos and colleagues, displayed low gonadotropin and sex steroids levels, and lacked development of the reproductive tract. Interestingly, in this study the authors also demonstrated that leptin increases the dephosphorylated (nuclear) form of Crtc1, and thereby regulates the transcription of specific neuropeptides involved in the control of the reproductive physiology (i.e., kisspeptin) [10]. Because of the contrasting findings observed by independent groups using similar techniques and mouse genetic backgrounds, further studies will be necessary to evaluate the contribution of Crtc1 to leptin's effects on the reproductive neuroendocrine axis.

\section{Brain circuitry engaged in leptin's action on reproductive control: redundancies for the benefit of the species}

Leptin receptors are expressed in a wide range of organs and tissues [361]. However, the literature now converges to a common view that most of leptin's actions, including those in the reproductive neuroendocrine axis, are mediated by the long-form LepR expressed in the central nervous system [78, 95]. The initial observations of dense LepR expression in hypothalamic sites and leptin-induced increases in LH pulsatility in a variety of species and both sexes suggested that GnRH neurons are direct targets of circulating leptin [199, 257, 347, 359]. This concept was later reinforced by the observation that immortalized GnRH (GT1) neurons and GnRH-expressing human neuroblasts (FNC-B4) express LepR and that leptin may directly alter GnRH cell activity [217, 236, 313, 361]. However, the expression of the LepR gene in GnRH neurons has been difficult to demonstrate. Recently, with the use of mouse models expressing reporter genes, it has become evident that mouse GnRH neurons express virtually no or very low levels of LepR [100, 208, 269]. The evaluation of the requirement of LepR expression in $\mathrm{GnRH}$ neurons for sexual maturation and fertility came with the use of conditional knockout mice. Quennell and colleagues demonstrated that the deletion of LepR from GnRH neurons produces no identifiable reproductive deficits [269]. Males and females show regular pubertal development, are fertile and retain normal fecundity. This study determined that LepR expression in GnRH neurons, if proven, is not required for leptin's effects on mouse reproductive physiology. Therefore, it seems reasonable to assume that leptin stimulation of GnRH secretion is primarily mediated by a relay station via interneurons that innervate $\mathrm{GnRH}$ cells. The search for these specific neuronal populations has become a critical issue to the field.

LepR is highly expressed in numerous brainstem and hypothalamic sites [59, 113, 121, 231, 232, 242, 294]. In the brainstem, the nucleus of the solitary tract (NTS) might possibly mediate leptin's effects as it functions as a sensory relay of the internal milieu via vagal afferents or the area postrema [132, 172, 175]. However, a role for the NTS or the brainstem in leptin's action on reproductive control is unlikely because deletion of LepR selectively from forebrain nuclei (CamKII $\alpha$-Cre mouse model) produced male and female mice with reproductive deficits similar to leptin-deficient mice [269]. These findings demonstrate that leptin action in the brainstem is not required for reproductive function. Rather, LepR-expressing neurons located in the forebrain are the main players.

\section{Stress-induced disruption of the reproductive function: the role of the paraventricular nucleus of the hypothalamus}

Food deprivation, severe caloric restriction and negative energy balance are well-described states of nutritional stress [74, 93]. In general, stressors of different origins activate the hypothalamus-pituitary-adrenal (HPA) axis primarily by inducing the secretion of corticotropin releasing hormone (CRH) into the hypophyseal portal system. CRH, in turn, stimulates adrenocorticotropin $(\mathrm{ACTH})$ release from the anterior pituitary gland and subsequent corticosterone production from the adrenal gland [152, 312]. The adenohypophyseal neuroendocrine CRH neurons are located in the medial parvicellular aspect of the paraventricular nucleus of the hypothalamus (PVH), a prominent hypothalamic structure involved in the coordination of a series of neuroendocrine and autonomic responses [282, 284]. Conditions of nutritional stress (i.e., perceived negative energy balance) activate the HPA axis, concomitant with a decrease in leptin and LH secretion [5, 216, 325]. Exogenous leptin infusion during fasting prevents the activation of the HPA axis and the suppression of the reproductive axis [5]. In light of these coordinated responses, several groups have postulated that the negative energy balance-induced decrease in LH secretion might be an inhibitory response triggered directly by the high activity of the HPA axis. The experimental approach selected to test this model was the use of 2-deoxyglucose (2DG)-induced blockade of cellular glucose utilization as a controlled experimental tool that mimics states of starvation. In this paradigm, 2DG increased corticosterone levels, 
and decreased leptin and LH secretion [246, 325, 338]. Pharmacologic inhibition of CRH signaling in 2DG treated female rats normalized LH levels [325]. However, while leptin treatment prevented the 2DG-induced increase in corticosterone, it had no effect on LH secretion [246]. Two important conclusions can be drawn from these findings: (a) the restraint of LH pulsatility caused by blockade of cellular glucose utilization appears to be mediated by CRH signaling in the brain; and (b) leptin's induction of LH secretion during negative energy balance is independent of the normalization of HPA axis activity and does not overcome the deleterious effects of lack of glucose availability.

Leptin-deficient $o b / o b$ mice also exhibit abnormal stimulation of the HPA axis [106]. Leptin administration to these mice inhibits the activity of the HPA axis by decreasing ACTH and corticosterone levels [11, 148]. However, the direct action of leptin on PVH CRHexpressing neurons is still uncertain and a series of apparent controversies deserves an attentive look. Early studies have proposed that leptin's effect on food intake may be attained by stimulation-not inhibition-of CRH neurons. For example, intracerebroventricular administration of leptin to fasted rats increased CRH mRNA levels in the PVH [291, 326]. This change was not observed in LepR-deficient Zucker rats, indicating that it is dependent on LepR signaling, not secondary to the stress of the experimental procedure. Leptin also stimulated CRH secretion from hypothalamic explants of rats and adrenalectomized mice [86, 169]. Because it is reasonable to expect that stimulation of neuroendocrine $\mathrm{CRH}$ neurons would induce ACTH and corticosterone production, these findings appear contradictory. However, CRH neurons in the PVH do not comprise a homogeneous population. Rather, they consist of neuroendocrine and autonomic components [281, 284]; therefore, data obtained from changes in CRH expression in the PVH as a whole may not be very informative. Moreover, the expression of LepR in the PVH is very low $[59,100,113,294]$ and the colocalization of LepR in PVH CRH neurons has not been clearly demonstrated. It is interesting though that leptin induces a neuronal response (Fos-immunoreactivity) in neurons of the ventral parvicellular subdivision of the PVH (PVHvp) in rats [109]. The PVHvp projects to sympathetic and parasympathetic preganglionic neurons in the brainstem and spinal cord, and a subset of these neurons coexpress CRH [281, 283, 316]. However, whether PVHvp CRH neurons have a critical role in leptin's physiology is still unsettled. In any event, leptin's effect on CRH secretion and/or neurotransmission appears to be achieved via indirect and/or independent pathways, and the response of specific neuroendocrine and/or autonomic neuronal populations may be defined by leptin-responsive neuronal inputs. One component of this circuitry is the arcuate nucleus [242, 292], a hypothalamic site, which has been extensively studied in the context of leptin's physiology.

\section{Arcuate nucleus: a prime sensor of the internal milieu}

The arcuate nucleus (Arc) lies adjacent to the median eminence, a key circumventricular organ located at the base of the hypothalamus [43, 132]. The median eminence contains fenestrated blood vessels that allow diffusion and interchange of bigger molecules (peptides and hormones) between the brain parenchyma and the bloodstream. Leptin can passively penetrate the brain through the circumventricular organs, with the highest levels of labeled-leptin binding observed in the Arc, surrounding the median eminence [20]. In the Arc, LepRb is expressed in a subset of proopiomelanocortin (POMC), neuropeptide Y/agouti related protein (NPY/AgRP) and Kiss1 neurons [22, 71, 306]. POMC and NPY/AgRP neurons mediate a diverse range of leptin's actions in metabolism [82, 114, 235, 290, 344,348 ] and several studies have identified these populations also as key players linking leptin action and reproduction.

The role of the melanocortin system (POMC and AgRP neurons) in the control of the HPG axis has been the focus of contentious debate. This is mainly due to inconsistencies described by independent laboratories using distinct approaches and the incomparable phenotypes of different species, mutant mice and genetically engineered mouse models. Humans with loss-of-function mutations of melanocortin signaling show no reproductive deficits [117, 190, 355], while in ewes, which are seasonal breeders, studies indicate that melanocortins relay leptin's action in the HPG axis [14, 15]. In rodents, inconsistent findings must be interpreted based on the experimental design and approach. Arc POMC neurons project to the preoptic area and make apparent synaptic contact with GnRH and kisspeptin cells $[89,201]$. One important issue to consider is that POMC, a complex preprohormone, generates neuroactive peptides (e.g., $\beta$-endorphin $/ \beta$ End and $\alpha$-melanocyte stimulating hormone/ $\alpha \mathrm{MSH})$ with seemingly contradictory effects on the reproductive axis and metabolism. $\alpha \mathrm{MSH}$ reduces food intake and stimulates lordosis behavior in female rats [6, 82, 141, 349], while $\beta$ End stimulates food consumption and inhibits GnRH/LH secretion [41, 136, 197]. Moreover, in rats, $\alpha$ MSH may stimulate or inhibit LH secretion depending on the internal milieu [66, 293]. Mice with lossof-function mutations in Pomc or melanocortin receptors (Mc3r or Mc4r) genes develop hyperphagic obesity [50, 81, 162] and subfertility later in life. Likewise, mice with a genetic mutation causing constitutive and ubiquitous expression of the agouti protein (lethal yellow/Ay) - a 
competitive antagonist of melanocortin receptors-are also obese and display abnormal estrous cycles and subfertility at older ages [142]. Whether the reproductive deficits of these mouse models are secondary to the deleterious effects of their metabolic dysfunction is currently unknown.

AgRP is expressed in a distinct population of Arc neurons and exhibits an antagonistic effect on melanocortin receptors [144, 252]. AgRP administration or pharmacologic blockade of MC4R blunted the LH surge in ovariectomized steroid-primed female rats [286, 336] and suppressed pulsatile release of LH in ovariectomized rhesus monkey [333]. Notably, in male rats, AgRP increased GnRH secretion from mediobasal hypothalamic explants and increased gonadotropins and sex steroids levels when injected into the cerebral ventricles [311].

These observations, although inconclusive, indicated that the melanocortin system might also mediate leptin's action in the neuroendocrine reproductive axis. Initial findings demonstrated that in female rats starved for 3 days, leptin administration partially restored the $\mathrm{LH}$ surge but the effect of leptin was blunted in the presence of MC4R antagonists [336]. However, pharmacological blockade of MC4R did not prevent the ability of leptin to activate the HPG axis in $o b / o b$ male mice [157]. Following the same line, deletion of LepR from POMC neurons, AgRP neurons, or both POMC and AgRP neurons caused no reported reproductive deficits in these mice $[18,330]$. In this regard, additional information can be extracted from leptin-signaling (STAT3)-deficient mice $\left(\mathrm{LRb}^{\mathrm{S} 1138} s / s\right)$. In these mice, as in $d b / d b$ and $o b / o b$ mice, the expression of hypothalamic POMC mRNA was reduced and AgRP mRNA was increased compared with control mice, demonstrating that STAT3 is required for the regulation of both mRNAs [23]; but while $d b / d b$ and $o b / o b$ mice were infertile, $s / s$ mice showed improved fertility indicating that normalization of melanocortin levels in the brain is not required for improvement of the reproductive function. It is interesting that deletion of LepR and insulin receptor selectively from POMC cells generated a mouse model with insulin resistance, hyperandrogenism, ovarian abnormalities and late onset of subfertility [154]. However, as noted before, it is not yet clear if the reproductive deficits observed also in this mouse model are caused by disruption of a direct melanocortin action on GnRH secretion or are secondary to their impaired metabolic function. Collectively, these findings indicate that, despite the initial evidence in female rats, leptin action in melanocortin neurons is not required for the development and maturation of the reproductive system in mice.

Studies from two independent laboratories have demonstrated that ablation of AgRP neurons or knockout of one allele of $M c 4 r$ gene corrected the infertility phenotype of leptin-signaling-deficient mice $[167,351]$. These publications clearly demonstrate that, although leptin action in melanocortin neurons is not required for reproductive function, blockade of a likely inhibitory action of $\mathrm{AgRP}$ on GnRH secretion is sufficient to improve fertility in leptin-signaling-deficient mouse models.

AgRP neurons coexpress the inhibitory neurotransmitter GABA, and NPY, a potent orexigenic peptide highly implicated in leptin's physiology [76, 82, 114, 144, 178, $290,348,350]$. The actions of NPY in reproductive control are highly dependent on several factors including steroid milieu, stage of development and expression of sex steroids receptors $[155,346]$. Administration of NPY to ovariectomized steroid-primed rats increases LH secretion [168, $179,278,329]$. In contrast, in the absence of gonadal steroids or in intact rats, NPY inhibits reproductive function as seen by decreased circulating levels of gonadotropins and sex steroids, decreased weight of the reproductive organs and decreased copulatory behavior in both sexes [76, 230, 260, 270, 353]. Intracerebroventricular administration of NPY antisera or blockade of NPY gene expression by antisense oligonucleotides diminished pulsatile GnRH secretion [176, 353], whereas NPY stimulated the release of $\mathrm{GnRH}$ from mediobasal hypothalamic explants and potentiated GnRH-stimulated gonadotropin release from the anterior pituitary gland [90, 177]. These findings may appear contradictory, but it is important to stress that NPY is expressed in several other brain sites outside the Arc, making some of the reports difficult to interpret or reconcile.

Conditions of negative energy balance such as food restriction, excess exercise and lactation, have been associated with elevated levels of hypothalamic NPY expression, and leptin-signaling-deficient obese mice exhibit high levels of Arc NPY [6, 267, 290, 307, 348]. Thus, it is reasonable to believe that high NPY expression in the Arc contributes to the decreased fertility observed in these conditions [13]. To test this hypothesis, a series of mouse models were generated. NPY knockout mice and mice with selective deletion of LepR from NPY/AgRP neurons display normal reproductive function [115, 330], but deletion of Npy gene expression in leptin-deficient $o b / o b$ mice improve their fertility [115]. One-third of double mutant $\mathrm{NPY}^{-/}$ob/ob male and $20 \%$ of female mice were fertile. Because previous studies have shown that food restriction ameliorates the reproductive capacity of $o b / o b$ male mice [194], it will be important to define whether the improved fertility of the $\mathrm{NPY}^{-1-}$ ob/ob mice is secondary to an improvement of their metabolic profile (e.g., decreased hyperglycemia and reduced adiposity).

The Arc houses one of the most potent regulators of the reproductive physiology, the kisspeptins (products of the KISS1/Kiss1 gene). A series of excellent reviews focused on the kisspeptin role in reproductive biology have been 
published in the last few years and may be consulted for further details $[80,251,263,320]$. Loss-of-function mutations in KISS1/Kiss1 or the kisspeptin receptor (GPR54/Gpr54) genes causes infertility due to lack of pubertal development and hypogonadotropic hypogonadism in humans and mice [92, 96, 195, 297, 323]. A steady increase in hypothalamic Kiss 1 and Gpr54 gene expression is observed across pubertal development and administration of kisspeptin to juvenile rodents induces vaginal opening, increases LH secretion and induces ovulation [247, 300, 319]. Notably, a subset of Kiss1 neurons in the Arc coexpress LepR but, in this regard, some inconsistencies are apparent. Using dual-labeled in situ hybridization in castrated male mice, Smith and colleagues reported $40 \% \mathrm{Kiss} 1 / \mathrm{LepR}$ colocalization [306]. In ovariectomized guinea pig, Qiu and collaborators reported $80 \%$ of Kiss1/LepR colocalization using electrophysiologic recordings and single cell PCR of Arc neurons [265]. In contrast, minimal colocalization has been reported using different lines of female Kiss1 reporter mice and female rats [89, 208, 324]. In female mice engineered to express green fluorescence protein (GFP) in Kiss1 neurons (or Tachykinin 2-expressing neurons), less than $10 \% \mathrm{Kiss} 1 /$ LepR coexpression was reported in intact mice and $15 \%$ colocalization was found in ovariectomized mice [89, 208]. In female rats, no colocalization has been observed [324]. Different techniques or approaches (e.g., dual in situ hybridization, dual immunohistochemistry, single cell PCR, reporter mice), species differences (i.e., mouse, rat and guinea pig) or the existence of an unreported sexual dimorphism in the response of Kiss1 neurons to leptin may account for these discrepancies. However, the percentage of colocalization is not always a good indicative of physiological relevance. For example, only around $30 \%$ of POMC neurons coexpress LepR, but their role in leptin's physiology is unequivocal [110, 290, 343, 344]. Following this concept, the requirement of leptin action in Kiss1 neurons was assessed with the use of conditional knockout mice (Cre-loxP system) in which LepR was selectively deleted from Kiss1 neurons [101]. Male and female Kiss1Cre/LepR-floxed mice showed normal pubertal development, sexual maturation and fertility, indicating that direct leptin action in Kiss1 neurons is not required for normal puberty onset and reproduction, in mice. Notably, a recent report demonstrated that female mice with ablation of kisspeptin neurons early in development exhibited no deficits in pubertal development and fertility [226]. While intriguing, this finding suggests that developmental adaptations may be triggered to allow reproduction and species survival. Therefore, it is also possible that systems redundancy and/or developmental adaptations may occur in mice with lack of leptin signaling in kisspeptin neurons. Additional studies will be necessary to test this hypothesis.
Several groups have reported a decrease in Kiss1 mRNA expression and kisspeptin production in conditions of low leptin levels (e.g., $o b / o b$ mice or wild-types in negative energy balance) [63, 174, 212, 268, 306]. Moreover, streptozotocin-injected diabetic male rats displayed decreased levels of hypothalamic Kiss1 mRNA concomitant with low circulating levels of leptin, insulin, LH and androgens [64]. Administration of leptin, but not insulin, increased hypothalamic Kiss 1 gene expression, and levels of LH and androgens. Collectively, these studies indicate that leptin administration may restore (or increase) Kiss1 mRNA expression in rodents in negative energy balance. Whether this effect is achieved via direct leptin action in Kiss 1 neurons or by the stimulation of leptin-responsive neurons that project to kisspeptin, still needs to be determined.

The existence of a complex interplay among Kiss1, POMC and NPY/AgRP neurons in the Arc has been reported [15, 16, 128]. For example, the melanocortin system may influence the reproductive physiology of ewes via actions in kisspeptin-expressing cells [15]. In mice, subpopulations of kisspeptin neurons in the preoptic area and Arc coexpress MC4R and, therefore, are also apt to respond to the melanocortin system [89]. As an alternative pathway, leptin may influence Kiss1 expression via projections from the ventral premammillary nucleus, a brain site recently shown to play a fundamental role in leptin's action on reproductive control [98, 101, 203, 208].

\section{Ventral premammillary nucleus: the emergence of a forgotten pathway}

Initial evidence for a role of ventral premammillary nucleus (PMV) neurons in reproductive control came from studies in rats focused on the contribution of sex odorants to the activation of the HPG axis. In response to opposite sex odors, males and females from different species exhibit increased circulating levels of gonadotropins and sex steroids [26, 85, 180, 214, 223, 264]. Odors are relayed by the main and accessory olfactory pathways and converge in the medial nucleus of the amygdala which in turn innervates several hypothalamic nuclei related to behavioral adjustments and hormonal secretion, including the PMV [57, $145,285,357]$. In female rats on proestrus, electrical stimulation of the medial nucleus of the amygdala precipitated LH secretion [25], a response that is blocked in rats with electrolytic lesions of the PMV [27]. Following copulation, PMV neurons appear activated (Fos immunoreactivity), a response that was later shown to be related to odor stimulation [65, 99, 188, 203, 356]. Projections from the PMV are particularly dense in forebrain sites related to the control of the HPG axis, in sexually dimorphic nuclei 
and in those components of vomeronasal circuitry [55, 275]. In particular, the PMV innervates kisspeptin neurons and GnRH cells in the preoptic area as well as GnRH terminals in the mediobasal hypothalamus/median eminence $[37,101,203,208,275]$. In addition, a high-tomoderate density of sex steroids-responsive neurons (estrogen receptors and androgen receptor) is also found in the PMV of rodents [233, 304]. Thus, PMV neurons are likely to integrate and convey sexually relevant signals from external and internal environments to relevant reproductive control sites in the brain.

The PMV houses a high density of neurons expressing LepR. Of these, a high proportion is depolarized (and most likely activated) by leptin [109, 113, 203, 208, 345]. These neurons coexpress the neurotransmitters glutamate and nitric oxide, and directly innervate GnRH cells [101, 102, 203, 208]. Together, these findings indicate that PMV neurons are potentially stimulated by leptin and may directly activate their terminal targets (e.g., kisspeptin and GnRH neurons) via the release of glutamate, a classical excitatory amino acid $[39,219]$.

The role of PMV neurons as a key site of leptin action in reproductive control has only recently been demonstrated in a series of experiments using conditional knockouts and excitotoxic lesions in rats and mice. Female rats with bilateral lesions of PMV neurons became anestrus during a transient period of 2-3 weeks [98]. After this time, their cyclicity was apparently normalized but, during proestrus, PMV-lesioned rats showed reduced estradiol and LH levels, GnRH mRNA expression and decreased activation of GnRH and AVPV neurons. Leptin administration to fasted PMV-lesioned rats failed to increase LH secretion, indicating that the PMV is a critical site for the stimulatory effects of leptin on fasting-induced suppression of the HPG axis. However, it is important to emphasize that only a subset of PMV neurons coexpress LepR [203] and, therefore, the effects of the excitotoxic lesions might result from disruption of pathways unrelated to leptin's physiology, but involved in the control of female neuroendocrine reproductive axis. Thus, to assess the role of PMV in leptin's physiology, a more selective approach was performed using the conditional knockout technique, in which LepR was endogenously re-expressed in PMV neurons of a LepR null reactivable mouse model $[84,101]$. Re-expression of LepR selectively in PMV neurons of LepR null female mice induced pubertal development and improved fertility; but, intriguingly, no amelioration of male infertility was observed [101]. These findings demonstrated that leptin action in PMV neurons of female mice is sufficient to induce puberty and improve fertility in the otherwise infertile LepR null mice. They also indicate that leptin's action in the reproductive function is sexually dimorphic and that alternative brain sites relay leptin's effects in male's reproduction. As discussed in previous sections, neurons in the Arc may convey signals from leptin levels to the male reproductive system. The role of LepR in the male PMV neurons still needs to be unraveled.

Due to the expected redundancy of the system, leptin action in PMV neurons may be sufficient but not required for reproduction in female mice. To test this, a more precise approach would be the selective deletion of LepR from PMV neurons using the Cre-loxP system. However, due to the lack of a mouse model in which Cre recombinase is driven by a gene expressed exclusively in PMV neurons, another strategy was used. PMV neurons of $o b / o b$ female mice were ablated by the bilateral administration of an excitotoxic agent (NMDA) and leptin was replaced in these mice. In PMV-lesioned $o b / o b$ mice, a significant delay in pubertal development was observed indicating that leptin action in the female PMV is required for an adequate maturation of the reproductive system [101]. However, after 35-40 days in the presence of a sexually experienced male, $80 \%$ of the PMV-lesioned mice showed sexual maturation as indicated by the presence of copulatory plugs, suggesting that alternative/redundant pathways (e.g., melanocortin system) were recruited to allow reproductive success. In agreement, deletion of LepR selectively from neurons expressing neuronal nitric oxide synthase (nNOS) delayed pubertal maturation in female mice [202]. LepR and nNOS are colocalized in neurons of several nuclei, including the PMV where colocalization rate is very high [102, 202, 203] reinforcing the relevance of PMV neurons as key site of leptin action in pubertal initiation.

Of note, several studies have suggested that leptin facilitates sexual behavior in female hamsters and rats $[135,334]$. The brain pathways involved in this effect by leptin are not known and the involvement of PMV neurons in the control/modulation of sexual behavior in males or females has not been demonstrated. However, it is interesting that a strong interconnection between the PMV and the ventrolateral subdivision of the ventromedial nucleus of the hypothalamus, a key site in female sexual behavior, has been reported $[55,56,275]$. The physiologic relevance of these reciprocal connections awaits further investigation.

\section{From satiety center to behavioral gate: the many faces of the ventromedial nucleus of the hypothalamus}

The ventromedial nucleus of the hypothalamus (VMH) has been the focus of the attention of many laboratories interested in the complex regulation of energy homeostasis since the seminal report by Hetherington and Ranson [153]. This study showed that bilateral electrolytic lesions centered in the VMH induce hyperphagic obesity, characterized by a remarkable increase in the adipose tissue mass. 
Subsequently, it was suggested that the lesions may have disrupted the internal connectivity of the medial hypothalamic nuclei and that other hypothalamic sites, including the $\mathrm{PVH}$, may have played a major role in this phenotype [114, 139]. The relevance of the VMH in metabolic regulation was reinstated with the demonstration of dense expression of receptors for metabolic cues (e.g., leptin and ghrelin) and the presence of glucosensing neurons $[112,113,181,277,294$, 308, 364]. However, the VMH, like most of the hypothalamic nuclei, is not a homogeneous structure. Rather, it is composed of distinct subdivisions with characteristic projection patterns [56]. The ventrolateral subdivision of the VMH (VMHvl) expresses sex steroids receptors, projects to reproductive control sites and plays a well-defined role in the female sexual behavior $[56,94,233,305]$. On the other hand, neurons in the dorsomedial subdivision of the VMH (VMHdm) are responsive to metabolic cues (e.g., leptin and insulin) and project to sites related to autonomic and circadian regulation [111, 185, 187]. Therefore, neurons in the VMHdm may influence energy balance by modulating autonomic responses, which include thermogenesis, hepatic glucose production, glucose utilization and secretion of insulin and glucagon [28, 88, 186, 210, 248].

The VMH is virtually the only site in the brain where the steroidogenic factor-1 (SF1) is expressed [163, 296]. SF1 is also found in gonads, adrenal and pituitary gland and, as the name implies, it is a key component of the steroidogenic cascade. Mice with deletion of SF1 gene ( $\mathrm{Nr} 5 \mathrm{al})$ show adrenal and gonadal agenesis, disrupted VMH formation and infertility [164, 211, 280, 302]. Notably, deletion of SF1 selectively from the central nervous system (i.e., from the $\mathrm{VMH}$ ) disrupted $\mathrm{VMH}$ neuronal connectivity and impaired female reproductive function [184]. These findings make the $\mathrm{VMH}$ a potential candidate to mediate the effects of leptin in reproductive control. Using the SF1Cre mouse model, two independent groups demonstrated that leptin signaling in VMH neurons is required for body weight homeostasis and adequate control of glycemia and thermogenesis [32, 97], but these mice (both male and female) are fertile. Thus, it was concluded that leptin signaling in the VMH is not required for leptin's effect in reproductive control. But as noted before, developmental adaptations and the redundancy of the reproductive circuitry should be taken into account. Further studies will be necessary to assess whether mice with leptin signaling only in VMH neurons show improvements in any aspect of their reproductive physiology.

\section{Relevance for reproductive human health}

Our understanding of leptin's biology has largely grown from experiments in rodents, but a series of studies has also been conducted in humans, demonstrating the unequivocal relevance of leptin for human's reproductive health. Women have higher leptin levels compared to men [229]. This difference is already apparent at birth; leptin is higher in cord blood of female infants [170, 225, 289]. In girls, a direct relationship between the increase in leptin and gonadal steroid levels has been observed during pubertal development, likely consequent to the increase in body fat. In late puberty, leptin levels are also higher in females [158]. Due to its strong positive correlation with BMI, higher leptin in women has been attributed to a higher adiposity [229]. However, in a cross sectional study of 204 subjects, gender differences in leptin levels persisted even when adjusted for body fat $[149,253]$. Moreover, studies demonstrated that women also have higher leptin pulsatility over a 24-h period [204, 229, 289]. Although still undefined, a plausible explanation for the gender difference could be the effects of testosterone to likely decrease leptin levels in men [213].

As discussed previously, leptin levels fall in states of acute energy deprivation, and this physiologic response is seen as an adaptive strategy of diverting energy resources away from processes that are not essential for immediate survival. Extreme exercise (e.g., ballet dancers and gymnasts) and anorexia nervosa are associated with low gonadotropin and leptin levels [105, 224, 340]. Nutritional support to patients with anorexia nervosa improved percent body fat, BMI, leptin and gonadotropin secretion [17]. Likewise, secondary amenorrhea has been associated with decreased leptin levels $(<2 \mathrm{mcg} / \mathrm{l})$ [189]. Leptin treatment in women with functional hypothalamic amenorrhea caused by increased exercise and decreased body weight improved gonadotropin pulsatility, endometrial thickness, ovarian volume and ovulation [341]. In addition, leptin treatment in 72-h fasted healthy men prevented the disruption of gonadotropin secretion [67].

Obese individuals are usually in a state of hyperleptinemia and leptin resistance [229, 301]. However, the direct adverse effects of high leptin levels on reproduction in obesity are not well defined. Hyperleptinemia has been shown to interfere with ovulation and inhibit follicular growth in mice ovaries [315]. In humans, studies in vitro showed that higher doses of leptin can interfere with the ability of the dominant follicle to produce estradiol by inhibiting the production of androgen substrate and decreasing the aromatization capacity of granulosa cells [1]. In obese men, fat mass and leptin are inversely correlated with circulating levels of testosterone. Moreover, following human chorionic gonadotropin (hCG) stimulation, obese individuals exhibited higher 17-hydroxyprogesterone (17-OHP)/testosterone ratio compared to control lean subjects. These findings suggest the existence of an enzymatic dysfunction in the conversion of 17-OHP to testosterone in 
the Leydig cells [166]. Whether this effect is caused by excess leptin needs further investigation.

Controversies regarding the association of leptin with polycystic ovarian syndrome (PCOS) exist. One study found that leptin levels are elevated in women with PCOS [44]. However, the investigators did not adjust their data for BMI or fat mass and therefore the relevance of their findings has been debated. Moreover, subsequent studies were not able to reproduce this initial data, refuting the concept that changes in leptin levels might play a role in the etiology of PCOS [138, 222, 261, 276, 298].

Lipodystrophy is associated with low leptin levels. In particular, leptin is marked reduced in individuals with congenital generalized lipodystrophy (CGL) and acquired generalized lipodystrophy (AGL), compared to familial partial lipodystrophy (FPL) and acquired partial lipodystrophy (APL) [146]. The prevalence of infertility and PCOS is higher in patients with lipodystrophy compared to the general population [173, 332]. Leptin therapy improved insulin sensitivity, decreased testosterone levels, increased sex hormone binding globulin (SHBG) and reversed the features of PCOS [209]. Recently, an interesting case has been reported of a young woman with CGL, undetectable leptin levels and primary amenorrhea who after treatment with leptin underwent menarche and adequate sexual maturation. Leptin therapy improved her metabolic complications and reproductive dysfunctions. The patient eventually became pregnant and was able to delivery at 37 weeks of gestation with minimal complications [218].

\section{Conclusion}

In recent years, the use of genetic modified mouse models and the advance of molecular mapping of brain circuitry have generated a considerable amount of information regarding leptin's action in the reproductive neuroendocrine axis. Using these techniques we have learned that leptin activates glutamatergic PMV neurons and inhibits GABAergic AgRP Arc neurons. Both populations, in turn, impinge on $\mathrm{GnRH}$ and/or kisspeptin neurons, potentially modulating the reproductive neuroendocrine axis. The integration of these opposite signals is crucial to the control of timely secretion of $\mathrm{GnRH}$ during pubertal maturation and in states of energetic challenges. Importantly, lack of leptin action in one of these neuronal groups does not preclude sexual maturation, indicating that one neuronal population can compensate the effects of the other. These redundancies and systems plasticity are fundamental features in reproductive biology, allowing procreation and species survival. In addition, the identification of alternative signaling pathways recruited by leptin will allow a better understanding of the mechanisms by which leptin acts as a permissive factor in pubertal maturation and reproduction.

Acknowledgments We would like to thank members and previous members of Elias laboratory (Roberta Cravo, Yun-Hee Choi, José Donato Jr, Renata Frazão and Dhirender Ratra) at the Department of Internal Medicine, Division of Hypothalamic Research, University of Texas Southwestern Medical Center, Dallas, TX, USA for the active participation in the data discussed in this review. The research in our laboratory has been funded by grants from NIH (R01HD061539, R01HD69702), Foundation for Prader-Willi Research, the Regents Scholar Award and Young Investigator Research Award from UTSW.

Open Access This article is distributed under the terms of the Creative Commons Attribution License which permits any use, distribution, and reproduction in any medium, provided the original author(s) and the source are credited.

\section{References}

1. Agarwal SK, Vogel K, Weitsman SR, Magoffin DA (1999) Leptin antagonizes the insulin-like growth factor-I augmentation of steroidogenesis in granulosa and theca cells of the human ovary. J Clin Endocrinol Metab 84:1072-1076

2. Ahima RS (2006) Adipose tissue as an endocrine organ. Obesity (Silver Spring) 14(Suppl 5):242S-249S

3. Ahima RS, Dushay J, Flier SN, Prabakaran D, Flier JS (1997) Leptin accelerates the onset of puberty in normal female mice. J Clin Invest 99:391-395

4. Ahima RS, Flier JS (2000) Leptin. Annu Rev Physiol 62:413-437

5. Ahima RS, Prabakaran D, Mantzoros C, Qu D, Lowell B, Maratos-Flier E, Flier JS (1996) Role of leptin in the neuroendocrine response to fasting. Nature 382:250-252

6. Ahima RS, Saper CB, Flier JS, Elmquist JK (2000) Leptin regulation of neuroendocrine systems. Front Neuroendocrinol 21:263-307

7. Ahmed ML, Ong KK, Dunger DB (2009) Childhood obesity and the timing of puberty. Trends Endocrinol Metab 20:237-242

8. Al-Qassab H, Smith MA, Irvine EE, Guillermet-Guibert J, Claret M, Choudhury AI, Selman C, Piipari K, Clements MK, Lingard S, Chandarana K, Bell JD, Barsh GS, Smith AJH, Batterham RL, Ashford MLJ, Vanhaesebroeck B, Withers DJ (2009) Dominant role of the $\mathrm{p} 110 \beta$ isoform of PI3K over $\mathrm{p} 110 \alpha$ in energy homeostasis regulation by POMC and AgRP neurons. Cell Metab 10:343-354

9. Almog B, Gold R, Tajima K, Dantes A, Salim K, Rubinstein M, Barkan D, Homburg R, Lessing JB, Nevo N, Gertler A, Amsterdam A (2001) Leptin attenuates follicular apoptosis and accelerates the onset of puberty in immature rats. Mol Cell Endocrinol 183:179-191

10. Altarejos JY, Goebel N, Conkright MD, Inoue H, Xie J, Arias CM, Sawchenko PE, Montminy M (2008) The Creb1 coactivator Crtc1 is required for energy balance and fertility. Nat Med 14:1112-1117

11. Arvaniti K, Huang Q, Richard D (2001) Effects of leptin and corticosterone on the expression of corticotropin-releasing hormone, agouti-related protein, and proopiomelanocortin in the brain of $o b / o b$ mouse. Neuroendocrinology 73:227-236

12. Attig L, Larcher T, Gertler A, Abdennebi-Najar L, Djiane J (2011) Postnatal leptin is necessary for maturation of numerous organs in newborn rats. Organogenesis 7:88-94 
13. Aubert ML, Pierroz DD, Gruaz NM, d'Alleves V, Vuagnat BA, Pralong FP, Blum WF, Sizonenko PC (1998) Metabolic control of sexual function and growth: role of neuropeptide $\mathrm{Y}$ and leptin. Mol Cell Endocrinol 140:107-113

14. Backholer K, Bowden M, Gamber K, Bjorbaek C, Iqbal J, Clarke IJ (2010) Melanocortins mimic the effects of leptin to restore reproductive function in lean hypogonadotropic ewes. Neuroendocrinology 91:27-40

15. Backholer K, Smith J, Clarke IJ (2009) Melanocortins may stimulate reproduction by activating orexin neurons in the dorsomedial hypothalamus and kisspeptin neurons in the preoptic area of the ewe. Endocrinology 150:5488-5497

16. Backholer K, Smith JT, Rao A, Pereira A, Iqbal J, Ogawa S, Li Q, Clarke IJ (2010) Kisspeptin cells in the ewe brain respond to leptin and communicate with neuropeptide $\mathrm{Y}$ and proopiomelanocortin cells. Endocrinology 151:2233-2243

17. Ballauff A, Ziegler A, Emons G, Sturm G, Blum WF, Remschmidt H, Hebebrand J (1999) Serum leptin and gonadotropin levels in patients with anorexia nervosa during weight gain. Mol Psychiatry 4:71-75

18. Balthasar N, Coppari R, McMinn J, Liu SM, Lee CE, Tang V, Kenny CD, McGovern RA, Chua SC Jr, Elmquist JK, Lowell BB (2004) Leptin receptor signaling in POMC neurons is required for normal body weight homeostasis. Neuron 42:983-991

19. Banks AS, Davis SM, Bates SH, Myers MG Jr (2000) Activation of downstream signals by the long form of the leptin receptor. J Biol Chem 275:14563-14572

20. Banks WA, Kastin AJ, Huang W, Jaspan JB, Maness LM (1996) Leptin enters the brain by a saturable system independent of insulin. Peptides 17:305-311

21. Barash IA, Cheung CC, Weigle DS, Ren H, Kabigting EB, Kuijper JL, Clifton DK, Steiner RA (1996) Leptin is a metabolic signal to the reproductive system. Endocrinology 137:31443147

22. Baskin DG, Breininger JF, Schwartz MW (1999) Leptin receptor mRNA identifies a subpopulation of neuropeptide $\mathrm{Y}$ neurons activated by fasting in rat hypothalamus. Diabetes 48:828-833

23. Bates SH, Stearns WH, Dundon TA, Schubert M, Tso AW, Wang Y, Banks AS, Lavery HJ, Haq AK, Maratos-Flier E, Neel BG, Schwartz MW, Myers MG Jr (2003) STAT3 signalling is required for leptin regulation of energy balance but not reproduction. Nature 421:856-859

24. Batt RAL, Everard DM, Gillies G, Wilkinson M, Wilson CA, Yeo TA (1982) Investigation into the hypogonadism of the obese mouse (genotype $o b / o b$ ). J Reprod Fertil 64:363-371

25. Beltramino C, Taleisnik S (1978) Facilitatory and inhibitory effects of electrochemical stimulation of the amygdala on the release of luteinizing hormone. Brain Res 144:95-107

26. Beltramino C, Taleisnik S (1983) Release of LH in the female rat by olfactory stimuli. Effect of the removal of the vomeronasal organs or lesioning of the accessory olfactory bulbs. Neuroendocrinology 36:53-58

27. Beltramino C, Taleisnik S (1985) Ventral premammillary nuclei mediate pheromonal-induced $\mathrm{LH}$ release stimuli in the rat. Neuroendocrinology 41:119-124

28. Bernardis LL, Frohman LA (1971) Effects of hypothalamic lesions at different loci on development of hyperinsulinemia and obesity in the weanling rat. J Comp Neurol 141:107-115

29. Bi L, Okabe I, Bernard DJ, Nussbaum RL (2002) Early embryonic lethality in mice deficient in the p110 $\beta$ catalytic subunit of PI 3-kinase. Mamm Genome 13:169-172

30. Bi L, Okabe I, Bernard DJ, Wynshaw-Boris A, Nussbaum RL (1999) Proliferative defect and embryonic lethality in mice homozygous for a deletion in the p110alpha subunit of phosphoinositide 3-kinase. J Biol Chem 274:10963-10968

31. Bideci A, Cinaz P, Hasanoglu A, Tumer L (2002) Leptin, insulin-like growth factor (IGF)-I and IGF binding protein-3 levels in children with constitutional delay of growth. J Pediatr Endocrinol Metab JPEM 15:41-46

32. Bingham NC, Anderson KK, Reuter AL, Stallings NR, Parker KL (2008) Selective loss of leptin receptors in the ventromedial hypothalamic nucleus results in increased adiposity and a metabolic syndrome. Endocrinology 149:2138-2148

33. Biro FM, Galvez MP, Greenspan LC, Succop PA, Vangeepuram N, Pinney SM, Teitelbaum S, Windham GC, Kushi LH, Wolff MS (2010) Pubertal assessment method and baseline characteristics in a mixed longitudinal study of girls. Pediatrics 126:e583-e590

34. Biro FM, Khoury P, Morrison JA (2006) Influence of obesity on timing of puberty. Int J Androl 29:272-277

35. Bittinger MA, McWhinnie E, Meltzer JC, Iourgenko V, Latario B, Liu X, Chen CH, Song CK, Garza D, Labow M (2004) Activation of cAMP response element-mediated gene expression by regulated nuclear transport of TORC proteins. Curr Biol $14: 2156-2161$

36. Bjorbaek C, Uotani S, da Silva B, Flier JS (1997) Divergent signaling capacities of the long and short isoforms of the leptin receptor. J Biol Chem 272:32686-32695

37. Boehm U, Zou Z, Buck LB (2005) Feedback loops link odor and pheromone signaling with reproduction. Cell 123:683-695

38. Boulton TG, Zhong Z, Wen Z, Darnell JE, Stahl N, Yancopoulos GD (1995) STAT3 activation by cytokines utilizing gp130 and related transducers involves a secondary modification requiring an H7-sensitive kinase. Proc Natl Acad Sci 92:6915-6919

39. Brann DW, Mahesh VB (1994) Excitatory amino acids: function and significance in reproduction and neuroendocrine regulation. Front Neuroendocrinol 15:3-49

40. Brannian JD, Hansen KA (2002) Leptin and ovarian folliculogenesis: implications for ovulation induction and ART outcomes. Semin Reprod Med 20:103-112

41. Bray GA (1993) The nutrient balance hypothesis: peptides, sympathetic activity, and food intake. Ann N Y Acad Sci 676:223-241

42. Breuillaud L, Halfon O, Magistretti PJ, Pralong FP, Cardinaux JR (2009) Mouse fertility is not dependent on the CREB coactivator Crtc1. Nat Med 15:989-990; author reply 991

43. Broadwell RD, Brightman MW (1976) Entry of peroxidase into neurons of the central and peripheral nervous systems from extracerebral and cerebral blood. J Comp Neurol 166:257-283

44. Brzechffa PR, Jakimiuk AJ, Agarwal SK, Weitsman SR, Buyalos RP, Magoffin DA (1996) Serum immunoreactive leptin concentrations in women with polycystic ovary syndrome. J Clin Endocrinol Metab 81:4166-4169

45. Buettner C, Muse ED, Cheng A, Chen L, Scherer T, Pocai A, Su K, Cheng B, Li X, Harvey-White J, Schwartz GJ, Kunos G, Rossetti L (2008) Leptin controls adipose tissue lipogenesis via central, STAT3-independent mechanisms. Nat Med 14:667-675

46. Buettner C, Pocai A, Muse ED, Etgen AM, Myers MG Jr, Rossetti L (2006) Critical role of STAT3 in leptin's metabolic actions. Cell Metab 4:49-60

47. Burgos-Ramos E, Chowen JA, Arilla-Ferreiro E, Canelles S, Argente J, Barrios V (2011) Chronic central leptin infusion modifies the response to acute central insulin injection by reducing the interaction of the insulin receptor with IRS2 and increasing its association with SOCS3. J Neurochem 117:175185

48. Burks DJ, de Mora JF, Schubert M, Withers DJ, Myers MG, Towery HH, Altamuro SL, Flint CL, White MF (2000) IRS-2 
pathways integrate female reproduction and energy homeostasis. Nature 407:377-382

49. Burt Solorzano CM, McCartney CR (2010) Obesity and the pubertal transition in girls and boys. Reproduction 140:399-410

50. Butler AA, Cone RD (2002) The melanocortin receptors: lessons from knockout models. Neuropeptides 36:77-84

51. Butte NF, Hopkinson JM, Nicolson MA (1997) Leptin in human reproduction: serum leptin levels in pregnant and lactating women. J Clin Endocrinol Metab 82:585-589

52. Cagampang FR, Maeda K, Yokoyama A, Ota K (1990) Effect of food deprivation on the pulsatile $\mathrm{LH}$ release in the cycling and ovariectomized female rat. Horm Metab Res 22:269-272

53. Cameron JL, Nosbisch C (1991) Suppression of pulsatile luteinizing hormone and testosterone secretion during short-term food restriction in the adult male rhesus monkey (Macaca mulatta). Endocrinology 128:1532-1540

54. Cameron JL, Weltzin TE, McConaha C, Helmreich DL, Kaye WH (1991) Slowing of pulsatile luteinizing hormone secretion in men after forty-eight hours of fasting. J Clin Endocrinol Metab 73:35-41

55. Canteras NS, Simerly RB, Swanson LW (1992) Projections of the ventral premammillary nucleus. J Comp Neurol 324:195-212

56. Canteras NS, Simerly RB, Swanson LW (1994) Organization of projections from the ventromedial nucleus of the hypothalamus: a Phaseolus vulgaris-leucoagglutinin study in the rat. J Comp Neurol 348:41-79

57. Canteras NS, Simerly RB, Swanson LW (1995) Organization of projections from the medial nucleus of the amygdala: a PHAL study in the rat. J Comp Neuronl 360:213-245

58. Cantley LC (2002) The phosphoinositide 3-kinase pathway. Science 296:1655-1657

59. Caron E, Sachot C, Prevot V, Bouret SG (2010) Distribution of leptin-sensitive cells in the postnatal and adult mouse brain. J Comp Neurol 518:459-476

60. Carro E, Pinilla L, Seoane LM, Considine RV, Aguilar E, Casanueva FF, Dieguez C (1997) Influence of endogenous leptin tone on the estrous cycle and luteinizing hormone pulsatility in female rats. Neuroendocrinology 66:375-377

61. Casanueva FF, Dieguez C (1999) Neuroendocrine regulation and actions of leptin. Front Neuroendocrinol 20:317-363

62. Castellano JM, Bentsen AH, Sánchez-Garrido MA, Ruiz-Pino F, Romero M, Garcia-Galiano D, Aguilar E, Pinilla L, Diéguez C, Mikkelsen JD, Tena-Sempere M (2011) Early metabolic programming of puberty onset: impact of changes in postnatal feeding and rearing conditions on the timing of puberty and development of the hypothalamic kisspeptin system. Endocrinology 152:3396-3408

63. Castellano JM, Navarro VM, Fernandez-Fernandez R, Nogueiras R, Tovar S, Roa J, Vazquez MJ, Vigo E, Casanueva FF, Aguilar E, Pinilla L, Dieguez C, Tena-Sempere M (2005) Changes in hypothalamic KiSS-1 system and restoration of pubertal activation of the reproductive axis by kisspeptin in undernutrition. Endocrinology 146:3917-3925

64. Castellano JM, Navarro VM, Fernandez-Fernandez R, Roa J, Vigo E, Pineda R, Dieguez C, Aguilar E, Pinilla L, TenaSempere M (2006) Expression of hypothalamic KiSS-1 system and rescue of defective gonadotropic responses by kisspeptin in streptozotocin-induced diabetic male rats. Diabetes 55:26022610

65. Cavalcante JC, Bittencourt JC, Elias CF (2006) Female odors stimulate CART neurons in the ventral premammillary nucleus of male rats. Physiol Behav 88:160-166

66. Celis ME (1985) Release of LH in response to alpha-MSH administration. Acta Physiol Pharmacol Latinoam 35:281-290
67. Chan JL, Heist K, DePaoli AM, Veldhuis JD, Mantzoros CS (2003) The role of falling leptin levels in the neuroendocrine and metabolic adaptation to short-term starvation in healthy men. J Clin Invest 111:1409-1421

68. Chan JL, Mantzoros CS (2005) Role of leptin in energy-deprivation states: normal human physiology and clinical implications for hypothalamic amenorrhoea and anorexia nervosa. Lancet 366:74-85

69. Chantry D, Vojtek A, Kashishian A, Holtzman DA, Wood C, Gray PW, Cooper JA, Hoekstra MF (1997) p110delta, a novel phosphatidylinositol 3-kinase catalytic subunit that associates with p85 and is expressed predominantly in leukocytes. J Biol Chem 272:19236-19241

70. Chehab FF, Lim ME, Lu R (1996) Correction of the sterility defect in homozygous obese female mice by treatment with the human recombinant leptin. Nat Genet 12:318-320

71. Cheung CC, Clifton DK, Steiner RA (1997) Proopiomelanocortin neurons are direct targets for leptin in the hypothalamus. Endocrinology 138:4489-4492

72. Cheung CC, Thornton JE, Kuijper JL, Weigle DS, Clifton DK, Steiner RA (1997) Leptin is a metabolic gate for the onset of puberty in the female rat. Endocrinology 138:855-858

73. Cheung CC, Thornton JE, Nurani SD, Clifton DK, Steiner RA (2001) A reassessment of leptin's role in triggering the onset of puberty in the rat and mouse. Neuroendocrinology 74:12-21

74. Chowers I, Einat R, Feldman S (1969) Effects of starvation on levels of corticotrophin releasing factor, corticotrophin and plasma corticosterone in rats. Acta Endocrinol (Copenh) 61:687-694

75. Chua SC Jr, Chung WK, Wu-Peng XS, Zhang Y, Liu SM, Tartaglia L, Leibel RL (1996) Phenotypes of mouse diabetes and rat fatty due to mutations in the OB (leptin) receptor [see comments]. Science 271:994-996

76. Clark JT, Kalra PS, Kalra SP (1985) Neuropeptide Y stimulates feeding but inhibits sexual behavior in rats. Obes Res 5:275-283

77. Clement K, Vaisse C, Lahlou N, Cabrol S, Pelloux V, Cassuto D, Gourmelen M, Dina C, Chambaz J, Lacorte JM, Basdevant A, Bougneres P, Lebouc Y, Froguel P, Guy-Grand B (1998) A mutation in the human leptin receptor gene causes obesity and pituitary dysfunction [see comments]. Nature 392:398-401

78. Cohen P, Zhao C, Cai X, Montez JM, Rohani SC, Feinstein P, Mombaerts P, Friedman JM (2001) Selective deletion of leptin receptor in neurons leads to obesity. J Clin Invest 108:11131121

79. Coleman DL (1978) Obese and diabetes: two mutant genes causing diabetes-obesity syndromes in mice. Diabetologia $14: 141-148$

80. Colledge WH (2009) Kisspeptins and GnRH neuronal signalling. Trends Endocrinol Metab 20:115-121

81. Cone RD (2005) Anatomy and regulation of the central melanocortin system. Nat Neurosci 8:571-578

82. Cone RD, Cowley MA, Butler AA, Fan W, Marks DL, Low MJ (2001) The arcuate nucleus as a conduit for diverse signals relevant to energy homeostasis. Int J Obes Relat Metab Disord 25(Suppl 5):S63-S67

83. Considine RV, Sinha MK, Heiman ML, Kriauciunas A, Stephens TW, Nyce MR, Ohannesian JP, Marco CC, McKee LJ, Bauer TL et al (1996) Serum immunoreactive-leptin concentrations in normal-weight and obese humans [see comments]. N Engl J Med 334:292-295

84. Coppari R, Ichinose M, Lee CE, Pullen AE, Kenny CD, McGovern RA, Tang V, Liu SM, Ludwig T, Chua SC Jr, Lowell BB, Elmquist JK (2005) The hypothalamic arcuate nucleus: a key site for mediating leptin's effects on glucose homeostasis and locomotor activity. Cell Metab 1:63-72 
85. Coquelin A, Clancy AN, Macrides F, Noble EP, Gorski RA (1984) Pheromonally induced release of luteinizing hormone in male mice: involvement of the vomeronasal system. J Neurosci 4:2230-2236

86. Costa A, Poma A, Martignoni E, Nappi G, Ur E, Grossman A (1997) Stimulation of corticotrophin-releasing hormone release by the obese (ob) gene product, leptin, from hypothalamic explants. NeuroReport 8:1131-1134

87. Cota D, Proulx K, Smith KA, Kozma SC, Thomas G, Woods SC, Seeley RJ (2006) Hypothalamic mTOR signaling regulates food intake. Science 312:927-930

88. Cox JE, Powley TL (1981) Intragastric pair feeding fails to prevent VMH obesity or hyperinsulinemia. Am J Physiol 240:E566-E572

89. Cravo RM, Margatho LO, Osborne-Lawrence S, Donato J Jr, Atkin S, Bookout AL, Rovinsky S, Frazao R, Lee CE, Gautron L, Zigman JM, Elias CF (2011) Characterization of Kiss1 neurons using transgenic mouse models. Neuroscience 173:37-56

90. Crowley WR, Hassid A, Kalra SP (1987) Neuropeptide Y enhances the release of luteinizing hormone (LH) induced by LH-releasing hormone. Endocrinology 120:941-945

91. Cunningham MJ, Clifton DK, Steiner RA (1999) Leptin's actions on the reproductive axis: perspectives and mechanisms. Biol Reprod 60:216-222

92. d'Anglemont de Tassigny X, Fagg LA, Dixon JPC, Day K, Leitch HG, Hendrick AG, Zahn D, Franceschini I, Caraty A, Carlton MBL, Aparicio SAJR, Colledge WH (2007) Hypogonadotropic hypogonadism in mice lacking a functional Kiss1 gene. Proc Natl Acad Sci 104:10714-10719

93. Dallman MF, Akana SF, Bhatnagar S, Bell ME, Choi S, Chu A, Horsley C, Levin N, Meijer O, Soriano LR, Strack AM, Viau V (1999) Starvation: early signals, sensors, and sequelae. Endocrinology 140:4015-4023

94. Davis PG, McEwen BS, Pfaff DW (1979) Localized behavioral effects of tritiated estradiol implants in the ventromedial hypothalamus of female rats. Endocrinology 104:898-903

95. de Luca C, Kowalski TJ, Zhang Y, Elmquist JK, Lee C, Kilimann MW, Ludwig T, Liu SM, Chua SC Jr (2005) Complete rescue of obesity, diabetes, and infertility in $d b / d b$ mice by neuron-specific LEPR-B transgenes. J Clin Invest 115:34843493

96. de Roux N, Genin E, Carel JC, Matsuda F, Chaussain JL, Milgrom E (2003) Hypogonadotropic hypogonadism due to loss of function of the KiSS1-derived peptide receptor GPR54. Proc Natl Acad Sci USA 100:10972-10976

97. Dhillon H, Zigman JM, Ye C, Lee CE, McGovern RA, Tang V, Kenny CD, Christiansen LM, White RD, Edelstein EA, Coppari R, Balthasar N, Cowley MA, Chua S Jr, Elmquist JK, Lowell BB (2006) Leptin directly activates SF1 neurons in the VMH, and this action by leptin is required for normal body-weight homeostasis. Neuron 49:191-203

98. Donato J Jr, Silva RJ, Sita LV, Lee S, Lee C, Lacchini S, Bittencourt JC, Franci CR, Canteras NS, Elias CF (2009) The ventral premammillary nucleus links fasting-induced changes in leptin levels and coordinated luteinizing hormone secretion. J Neurosci 29:5240-5250

99. Donato J Jr, Cavalcante JC, Silva RJ, Teixeira AS, Bittencourt JC, Elias CF (2010) Male and female odors induce Fos expression in chemically defined neuronal population. Physiol Behav 99:67-77

100. Donato J Jr, Cravo RM, Frazao R, Elias CF (2011) Hypothalamic sites of leptin action linking metabolism and reproduction. Neuroendocrinology 93:9-18

101. Donato J Jr, Cravo RM, Frazao R, Gautron L, Scott MM, Lachey J, Castro IA, Margatho LO, Lee S, Lee C, Richardson JA, Friedman J, Chua S Jr, Coppari R, Zigman JM, Elmquist JK,
Elias CF (2011) Leptin's effect on puberty in mice is relayed by the ventral premammillary nucleus and does not require signaling in Kiss 1 neurons. J Clin Invest 121:355-368

102. Donato J Jr, Frazao R, Fukuda M, Vianna CR, Elias CF (2010) Leptin induces phosphorylation of neuronal nitric oxide synthase in defined hypothalamic neurons. Endocrinology 151: $5415-5427$

103. Drasher ML, Dicke MW, Lane PW (1955) Physiological differences in uteri of obese stock mice. J Hered 46:209-212

104. Dunger DB, Ahmed ML, Ong KK (2005) Effects of obesity on growth and puberty. Best Pract Res Clin Endocrinol Metab 19:375-390

105. Eckert ED, Pomeroy C, Raymond N, Kohler PF, Thuras P, Bowers CY (1998) Leptin in anorexia nervosa. J Clin Endocrinol Metab 83:791-795

106. Edwardson JA, Hough CAM (1975) The pituitary-adrenal system of the genetically obese $(o b / o b)$ mouse. J Endocrinol 65:99-107

107. El-Eshmawy M, Abdel Aal I, El hawary A (2010) Association of ghrelin and leptin with reproductive hormones in constitutional delay of growth and puberty. Reprod Biol Endocrinol 8:153

108. Elias CF (2012) Leptin action in pubertal development: recent advances and unanswered questions. Trends Endocrinol Metab 23:9-15

109. Elias CF, Kelly JF, Lee CE, Ahima RS, Drucker DJ, Saper CB, Elmquist JK (2000) Chemical characterization of leptin-activated neurons in the rat brain. J Comp Neurol 423:261-281

110. Elias CF, Lee C, Kelly J, Aschkenasi C, Ahima RS, Couceyro PR, Kuhar MJ, Saper CB, Elmquist JK (1998) Leptin activates hypothalamic CART neurons projecting to the spinal cord. Neuron 21:1375-1385

111. Elmquist JK, Ahima RS, Elias CF, Flier JS, Saper CB (1998) Leptin activates distinct projections from the dorsomedial and ventromedial hypothalamic nuclei. Proc Natl Acad Sci USA 95:741-746

112. Elmquist JK, Ahima RS, Maratos-Flier E, Flier JS, Saper CB (1997) Leptin activates neurons in ventrobasal hypothalamus and brainstem. Endocrinology 138:839-842

113. Elmquist JK, Bjorbaek C, Ahima RS, Flier JS, Saper CB (1998) Distributions of leptin receptor mRNA isoforms in the rat brain. J Comp Neurol 395:535-547

114. Elmquist JK, Elias CF, Saper CB (1999) From lesions to leptin: hypothalamic control of food intake and body weight. Neuron 22:221-232

115. Erickson JC, Hollopeter G, Palmiter RD (1996) Attenuation of the obesity syndrome of $o b / o b$ mice by the loss of neuropeptide $\mathrm{Y}$ [see comments]. Science 274:1704-1707

116. Farooqi IS (2002) Leptin and the onset of puberty: insights from rodent and human genetics. Semin Reprod Med 20:139-144

117. Farooqi IS, O'Rahilly S (2006) Genetics of obesity in humans. Endocr Rev 27:710-718

118. Farooqi IS, Wangensteen T, Collins S, Kimber W, Matarese G, Keogh JM, Lank E, Bottomley B, Lopez-Fernandez J, FerrazAmaro I, Dattani MT, Ercan O, Myhre AG, Retterstol L, Stanhope R, Edge JA, McKenzie S, Lessan N, Ghodsi M, De Rosa V, Perna F, Fontana S, Barroso I, Undlien DE, O'Rahilly S (2007) Clinical and molecular genetic spectrum of congenital deficiency of the leptin receptor. N Engl J Med 356:237-247

119. Fatima W, Shahid A, Imran M, Manzoor J, Hasnain S, Rana S, Mahmood S (2011) Leptin deficiency and leptin gene mutations in obese children from Pakistan. Int J Pediatr Obes IJPO Off J Int Assoc Study Obes 6:419-427

120. Fazeli M, Zarkesh-Esfahani H, Wu Z, Maamra M, Bidlingmaier M, Pockley AG, Watson PH, Matarese G, Strasburger CJ, Ross RJM (2006) Identification of a monoclonal antibody against the leptin receptor that acts as an antagonist and blocks human 
monocyte and T cell activation. J Immunol Methods 312:190_ 200

121. Fei H, Okano HJ, Li C, Lee GH, Zhao C, Darnell R, Friedman JM (1997) Anatomic localization of alternatively spliced leptin receptors $(\mathrm{Ob}-\mathrm{R})$ in mouse brain and other tissues. Proc Natl Acad Sci USA 94:7001-7005

122. Finn PD, Cunningham MJ, Pau KY, Spies HG, Clifton DK, Steiner RA (1998) The stimulatory effect of leptin on the neuroendocrine reproductive axis of the monkey. Endocrinology 139:4652-4662

123. Fischer-Posovszky P, von Schnurbein J, Moepps B, Lahr G, Strauss G, Barth TF, Kassubek J, Muhleder H, Moller P, Debatin KM, Gierschik P, Wabitsch M (2010) A new missense mutation in the leptin gene causes mild obesity and hypogonadism without affecting $\mathrm{T}$ cell responsiveness. J Clin Endocrinol Metab 95:2836-2840

124. Flier JS (1998) Clinical review 94: what's in a name? In search of leptin's physiologic role. J Clin Endocrinol Metab 83:1407-1413

125. Foukas LC, Claret M, Pearce W, Okkenhaug K, Meek S, Peskett E, Sancho S, Smith AJH, Withers DJ, Vanhaesebroeck B (2006) Critical role for the p110[alpha] phosphoinositide-3-OH kinase in growth and metabolic regulation. Nature 441:366-370

126. Frisch RE (1985) Fatness, menarche, and female fertility. Perspect Biol Med 28:611-633

127. Frisch RE (1994) The right weight: body fat, menarche and fertility. Proc Nutr Soc 53:113-129

128. Fu L-Y, van den Pol AN (2010) Kisspeptin directly excites anorexigenic proopiomelanocortin neurons but inhibits orexigenic neuropeptide Y cells by an indirect synaptic mechanism. J Neurosci 30:10205-10219

129. Galgani JE, Greenway FL, Caglayan S, Wong ML, Licinio J, Ravussin E (2010) Leptin replacement prevents weight lossinduced metabolic adaptation in congenital leptin-deficient patients. J Clin Endocrinol Metab 95:851-855

130. Gambino YP, Maymó JL, Pérez Pérez A, Calvo JC, SánchezMargalet V, Varone CL (2012) Elsevier trophoblast research award lecture: molecular mechanisms underlying estrogen functions in trophoblastic cells-focus on leptin expression. Placenta 33(Supplement):S63-S70

131. Gangloff Y-G, Mueller M, Dann SG, Svoboda P, Sticker M, Spetz J-F, Um SH, Brown EJ, Cereghini S, Thomas G, Kozma SC (2004) Disruption of the mouse mTOR gene leads to early postimplantation lethality and prohibits embryonic stem cell development. Mol Cell Biol 24:9508-9516

132. Ganong WF (2000) Circumventricular organs: definition and role in the regulation of endocrine and autonomic function. Clin Exp Pharmacol Physiol 27:422-427

133. Gao Q, Mezei G, Nie Y, Rao Y, Choi CS, Bechmann I, Leranth C, Toran-Allerand D, Priest CA, Roberts JL, Gao XB, Mobbs C, Shulman GI, Diano S, Horvath TL (2007) Anorectic estrogen mimics leptin's effect on the rewiring of melanocortin cells and Stat3 signaling in obese animals. Nat Med 13:89-94

134. Gao Q, Wolfgang MJ, Neschen S, Morino K, Horvath TL, Shulman GI, Fu XY (2004) Disruption of neural signal transducer and activator of transcription 3 causes obesity, diabetes, infertility, and thermal dysregulation. Proc Natl Acad Sci USA 101:4661-4666

135. García-Juárez M, Beyer C, Soto-Sánchez A, Domínguez-Ordoñez R, Gómora-Arrati P, Lima-Hernández FJ, Eguibar JR, Etgen AM, González-Flores O (2011) Leptin facilitates lordosis behavior through GnRH-1 and progestin receptors in estrogenprimed rats. Neuropeptides 45:63-67

136. Gilbeau PM, Almirez RG, Holaday JW, Smith CG (1985) Opioid effects on plasma concentrations of luteinizing hormone and prolactin in the adult male rhesus monkey. J Clin Endocrinol Metab 60:299-305

137. Gill MS, Hall CM, Tillmann V, Clayton PE (1999) Constitutional delay in growth and puberty (CDGP) is associated with hypoleptinaemia. Clin Endocrinol 50:721-726

138. Glintborg D, Andersen M, Hagen C, Frystyk J, Hulstrom V, Flyvbjerg A, Hermann AP (2006) Evaluation of metabolic risk markers in polycystic ovary syndrome (PCOS). Adiponectin, ghrelin, leptin and body composition in hirsute PCOS patients and controls. Eur J Endocrinol 155:337-345

139. Gold RM (1973) Hypothalamic obesity: the myth of the ventromedial nucleus. Science 182:488-490

140. Gonzalez LC, Pinilla L, Tena-Sempere M, Aguilar E (1999) Leptin(116-130) stimulates prolactin and luteinizing hormone secretion in fasted adult male rats. Neuroendocrinology 70:213-220

141. Gonzalez MI, Celis ME, Hole DR, Wilson CA (1993) Interaction of oestradiol, alpha-melanotrophin and noradrenaline within the ventromedial nucleus in the control of female sexual behaviour. Neuroendocrinology 58:218-226

142. Granholm NH, Jeppesen KW, Japs RA (1986) Progressive infertility in female lethal yellow mice (Ay/a; strain C57BL/6J). J Reprod Fertil 76:279-287

143. Gruaz NM, Lalaoui M, Pierroz DD, Englaro P, Sizonenko PC, Blum WF, Aubert ML (1998) Chronic administration of leptin into the lateral ventricle induces sexual maturation in severely food-restricted female rats. J Neuroendocrinol 10:627-633

144. Hahn TM, Breininger JF, Baskin DG, Schwartz MW (1998) Coexpression of Agrp and NPY in fasting-activated hypothalamic neurons. Nat Neurosci 1:271-272

145. Halpern M, Martinez-Marcos A (2003) Structure and function of the vomeronasal system: an update. Prog Neurobiol 70:245-318

146. Haque WA, Shimomura I, Matsuzawa Y, Garg A (2002) Serum adiponectin and leptin levels in patients with lipodystrophies. J Clin Endocrinol Metab 87:2395

147. Hara K, Yonezawa K, Weng Q-P, Kozlowski MT, Belham C, Avruch J (1998) Amino acid sufficiency and mTOR regulate p70 S6 kinase and eIF-4E BP1 through a common effector mechanism. J Biol Chem 273:14484-14494

148. Harris RBS, Zhou J, Redmann SM, Smagin GN, Smith SR, Rodgers E, Zachwieja JJ (1998) A leptin dose-response study in obese $(o b / o b)$ and Lean (+/?) mice. Endocrinology 139:8-19

149. Havel PJ, Kasim-Karakas S, Dubuc GR, Mueller W, Phinney SD (1996) Gender differences in plasma leptin concentrations. Nat Med 2:949-950

150. Henson MC, Castracane VD (2006) Leptin in pregnancy: an update. Biol Reprod 74:218-229

151. Hentges K, Sirry B, Gingeras A-C, Sarbassov D, Sonenberg N, Sabatini DM, Peterson AS (2001) FRAP/mTOR is required for proliferation and patterning during embryonic development in the mouse. Proc Natl Acad Sci 98:13796-13801

152. Herman JP, Prewitt CM, Cullinan WE (1996) Neuronal circuit regulation of the hypothalamo-pituitary-adrenocortical stress axis. Critical Rev Neurobiol 10:371-394

153. Hetherington AW, Ranson SW (1940) Hypothalamic lesions and adiposity in the rat. Anat Rec 78:149-172

154. Hill JW, Elias CF, Fukuda M, Williams KW, Berglund ED, Holland WL, Cho YR, Chuang JC, Xu Y, Choi M, Lauzon D, Lee CE, Coppari R, Richardson JA, Zigman JM, Chua S, Scherer PE, Lowell BB, Bruning JC, Elmquist JK (2010) Direct insulin and leptin action on pro-opiomelanocortin neurons is required for normal glucose homeostasis and fertility. Cell Metab 11:286-297

155. Hill JW, Elmquist JK, Elias CF (2008) Hypothalamic pathways linking energy balance and reproduction. Am J Physiol Endocrinol Metab 294:E827-E832 
156. Hill JW, Williams KW, Ye C, Luo J, Balthasar N, Coppari R, Cowley MA, Cantley LC, Lowell BB, Elmquist JK (2008) Acute effects of leptin require PI3K signaling in hypothalamic proopiomelanocortin neurons in mice. $J$ Clin Invest 118:1796-1805

157. Hohmann JG, Teal TH, Clifton DK, Davis J, Hruby VJ, Han G, Steiner RA (2000) Differential role of melanocortins in mediating leptin's central effects on feeding and reproduction. Am J Physiol Regul Integr Comp Physiol 278:R50-R59

158. Horlick MB, Rosenbaum M, Nicolson M, Levine LS, Fedun B, Wang J, Pierson RN Jr, Leibel RL (2000) Effect of puberty on the relationship between circulating leptin and body composition. J Clin Endocrinol Metab 85:2509-2518

159. Horsch D, Kahn CR (1999) Region-specific mRNA expression of phosphatidylinositol 3-kinase regulatory isoforms in the central nervous system of C57BL/6J mice. J Comp Neurol 415:105-120

160. Howell JJ, Manning BD (2011) mTOR couples cellular nutrient sensing to organismal metabolic homeostasis. Trends Endocrinol Metab 22:94-102

161. Hummel KP (1957) Transplantation of ovaries of the obese mouse. Anat Rec 128:569

162. Huszar D, Lynch CA, Fairchild-Huntress V, Dunmore JH, Fang Q, Berkemeier LR, Gu W, Kesterson RA, Boston BA, Cone RD, Smith FJ, Campfield LA, Burn P, Lee F (1997) Targeted disruption of the melanocortin-4 receptor results in obesity in mice. Cell 88:131-141

163. Ikeda Y, Luo X, Abbud R, Nilson JH, Parker KL (1995) The nuclear receptor steroidogenic factor 1 is essential for the formation. Mol Endocrinol 9:478-486

164. Ikeda Y, Luo X, Abbud R, Nilson JH, Parker KL (1995) The nuclear receptor steroidogenic factor 1 is essential for the formation of the ventromedial hypothalamic nucleus. Mol Endocrinol 9:478-486

165. Ingalls AM, Dickie MM, Snell GD (1950) Obese, a new mutation in the house mouse. J Hered 41:317-318

166. Isidori AM, Caprio M, Strollo F, Moretti C, Frajese G, Isidori A, Fabbri A (1999) Leptin and androgens in male obesity: evidence for leptin contribution to reduced androgen levels. J Clin Endocrinol Metab 84:3673-3680

167. Israel DD, Sheffer-Babila S, de Luca C, Jo YH, Liu SM, Xia Q, Spergel DJ, Dun SL, Dun NJ, Chua SC Jr (2012) Effects of leptin and melanocortin signaling interactions on pubertal development and reproduction. Endocrinology 153:2408-2419

168. Jain MR, Pu S, Kalra PS, Kalra SP (1999) Evidence that stimulation of two modalities of pituitary luteinizing hormone release in ovarian steroid-primed ovariectomized rats may involve neuropeptide Y Y1 and Y4 receptors. Endocrinology 140:5171-5177

169. Jang M, Mistry AM, Swick AG, Romsos DR (2000) Leptin rapidly inhibits hypothalamic neuropeptide $\mathrm{Y}$ secretion and stimulates corticotropin-releasing hormone secretion in adrenalectomized mice. J Nutr 130:2813-2820

170. Jaquet D, Leger J, Levy-Marchal C, Oury JF, Czernichow P (1998) Ontogeny of leptin in human fetuses and newborns: effect of intrauterine growth retardation on serum leptin concentrations. J Clin Endocrinol Metab 83:1243-1246

171. Jasik CB, Lustig RH (2008) Adolescent obesity and puberty: the "Perfect Storm". Ann N Y Acad Sci 1135:265-279

172. Johnson A, Gross P (1993) Sensory circumventricular organs and brain homeostatic pathways. FASEB J 7:678-686

173. Joy TR, Hegele RA (2008) Prevalence of reproductive abnormalities among women with familial partial lipodystrophy. Endocr Pract Off J Am Coll Endocrinol Am Assoc Clinical Endocrinol 14:1126-1132
174. Kalamatianos T, Grimshaw SE, Poorun R, Hahn JD, Coen CW (2008) Fasting reduces KiSS-1 expression in the anteroventral periventricular nucleus (AVPV): effects of fasting on the expression of KiSS-1 and neuropeptide Y in the AVPV or arcuate nucleus of female rats. J Neuroendocrinol 20:1089-1097

175. Kalia M, Sullivan JM (1982) Brainstem projections of sensory and motor components of the vagus nerve in the rat. J Comp Neurol 211:248-265

176. Kalra PS, Bonavera JJ, Kalra SP (1995) Central administration of antisense oligodeoxynucleotides to neuropeptide Y (NPY) mRNA reveals the critical role of newly synthesized NPY in regulation of LHRH release. Regul Pept 59:215-220

177. Kalra SP, Crowley WR (1992) Neuropeptide Y: a novel neuroendocrine peptide in the control of pituitary hormone secretion, and its relation to luteinizing hormone. Front Neuroendocrinol 13:1-46

178. Kalra SP, Kalra PS (2003) Neuropeptide Y: a physiological orexigen modulated by the feedback action of ghrelin and leptin. Endocrine 22:49-55

179. Kalra SP, Kalra PS, Sahu A, Crowley WR (1987) Gonadal steroids and neurosecretion: facilitatory influence on LHRH and neuropeptide Y. J Steroid Biochem 27:677-682

180. Kamel F, Wright WW, Mock EJ, Frankel AI (1977) The influence of mating and related stimuli on plasma levels of luteinizing hormone, follicle stimulating hormone, prolactin, and testosterone in the male rat. Endocrinology 101:421-429

181. Kang L, Routh VH, Kuzhikandathil EV, Gaspers LD, Levin BE (2004) Physiological and molecular characteristics of rat hypothalamic ventromedial nucleus glucosensing neurons. Diabetes 53:549-559

182. Kennedy GC, Mitra J (1963) Body weight and food intake as initiating factors for puberty in the rat. J Physiol 166:408-418

183. Khamzina L, Veilleux A, Bergeron S, Marette A (2005) Increased activation of the mammalian target of rapamycin pathway in liver and skeletal muscle of obese rats: possible involvement in obesity-linked insulin resistance. Endocrinology 146:1473-1481

184. Kim KW, Li S, Zhao H, Peng B, Tobet SA, Elmquist JK, Parker KL, Zhao L (2010) CNS-specific ablation of steroidogenic factor 1 results in impaired female reproductive function. Mol Endocrinol 24:1240-1250

185. Kim KW, Sohn J-W, Kohno D, Xu Y, Williams KW, Elmquist JK (2011) SF-1 in the ventral medial hypothalamic nucleus: a key regulator of homeostasis. Mol Cell Endocrinol 336:219-223

186. Kim KW, Zhao L, Donato J Jr, Kohno D, Xu Y, Elias CF, Lee C, Parker KL, Elmquist JK (2011) Steroidogenic factor 1 directs programs regulating diet-induced thermogenesis and leptin action in the ventral medial hypothalamic nucleus. Proc Natl Acad Sci USA 108:10673-10678

187. Klockener T, Hess S, Belgardt BF, Paeger L, Verhagen LA, Husch A, Sohn JW, Hampel B, Dhillon H, Zigman JM, Lowell BB, Williams KW, Elmquist JK, Horvath TL, Kloppenburg P, Bruning JC (2011) High-fat feeding promotes obesity via insulin receptor/PI3K-dependent inhibition of SF-1 VMH neurons. Nat Neurosci 14:911-918

188. Kollack-Walker S, Newman SW (1995) Mating and agonistic behavior produce different patterns of Fos immunolabeling in the male Syrian hamster brain. Neuroscience 66:721-736

189. Kopp W, Blum WF, von Prittwitz S, Ziegler A, Lubbert H, Emons G, Herzog W, Herpertz S, Deter HC, Remschmidt H, Hebebrand J (1997) Low leptin levels predict amenorrhea in underweight and eating disordered females. Mol Psychiatry $2: 335-340$

190. Krude H, Biebermann H, Luck W, Horn R, Brabant G, Gruters A (1998) Severe early-onset obesity, adrenal insufficiency and 
red hair pigmentation caused by POMC mutations in humans. Nat Genet 19:155-157

191. Lado-Abeal J, Hickox JR, Cheung TL, Veldhuis JD, Hardy DM, Norman RL (2000) Neuroendocrine consequences of fasting in adult male macaques: effects of recombinant rhesus macaque leptin infusion. Neuroendocrinology 71:196-208

192. Lado-Abeal J, Lukyanenko YO, Swamy S, Hermida RC, Hutson JC, Norman RL (1999) Short-term leptin infusion does not affect circulating levels of $\mathrm{LH}$, testosterone or cortisol in foodrestricted pubertal male rhesus macaques. Clin Endocrinol (Oxf) 51:41-51

193. Lane PW (1959) The pituitary-gonad response of genetically obese mice in parabiosis with thin and obese siblings. Endocrinology 65:863-868

194. Lane PW, Dickie MM (1954) Fertile obese male mice. Relative sterility in obese males corrected by dietary restrictions. J Hered 45:56-58

195. Lapatto R, Pallais JC, Zhang D, Chan Y-M, Mahan A, Cerrato F, Le WW, Hoffman GE, Seminara SB (2007) Kiss1/mice exhibit more variable hypogonadism than Gpr54/mice. Endocrinology 148:4927-4936

196. Laplante M, Sabatini DM (2012) mTOR signaling in growth control and disease. Cell 149:274-293

197. Leadem CA, Kalra SP (1985) Effects of endogenous opioid peptides and opiates on luteinizing hormone and prolactin secretion in ovariectomized rats. Neuroendocrinology 41:342-352

198. Lebrethon MC, Vandersmissen E, Gerard A, Parent AS, Bourguignon JP (2000) Cocaine and amphetamine-regulatedtranscript peptide mediation of leptin stimulatory effect on the rat gonadotropin-releasing hormone pulse generator in vitro. J Neuroendocrinol 12:383-385

199. Lebrethon MC, Vandersmissen E, Gerard A, Parent AS, Junien JL, Bourguignon JP (2000) In vitro stimulation of the prepubertal rat gonadotropin-releasing hormone pulse generator by leptin and neuropeptide $\mathrm{Y}$ through distinct mechanisms. Endocrinology 141:1464-1469

200. Lee GH, Proenca R, Montez JM, Carroll KM, Darvishzadeh JG, Lee JI, Friedman JM (1996) Abnormal splicing of the leptin receptor in diabetic mice. Nature 379:632-635

201. Leranth C, MacLusky NJ, Shanabrough M, Naftolin F (1988) Immunohistochemical evidence for synaptic connections between pro-opiomelanocortin-immunoreactive axons and LH$\mathrm{RH}$ neurons in the preoptic area of the rat. Brain Res 449:167-176

202. Leshan RL, Greenwald-Yarnell M, Patterson CM, Gonzalez IE, Myers MG Jr (2012) Leptin action through hypothalamic nitric oxide synthase-1-expressing neurons controls energy balance. Nat Med 18(5):820-823

203. Leshan RL, Louis GW, Jo Y-H, Rhodes CJ, Munzberg H, Myers MG Jr (2009) Direct innervation of GnRH neurons by metabolic- and sexual odorant-sensing leptin receptor neurons in the hypothalamic ventral premammillary nucleus. J Neurosci 29:3138-3147

204. Licinio J, Mantzoros C, Negrao AB, Cizza G, Wong ML, Bongiorno PB, Chrousos GP, Karp B, Allen C, Flier JS, Gold PW (1997) Human leptin levels are pulsatile and inversely related to pituitary-adrenal function [see comments]. Nat Med 3:575-579

205. Licinio J, Milane M, Thakur S, Whelan F, Yildiz BO, Delibasi T, de Miranda PB, Ozata M, Bolu E, Depaoli A, Wong ML (2007) Effects of leptin on intake of specific micro- and macronutrients in a woman with leptin gene deficiency studied off and on leptin at stable body weight. Appetite 49:594-599

206. Licinio J, Negrao AB, Mantzoros CS, Kaklamani V, Wong ML, Bongiorno PB, Mulla A, Cearnal L, Veldhuis JD, Flier JS,
McCann SM, Gold PW (1998) Synchronicity of frequently sampled, 24-h concentrations of circulating leptin, luteinizing hormone, and estradiol in healthy women. Proc Natl Acad Sci USA 95:2541-2546

207. Lloyd RV, Jin L, Tsumanuma I, Vidal S, Kovacs K, Horvath E, Scheithauer BW, Couce ME, Burguera B (2001) Leptin and leptin receptor in anterior pituitary function. Pituitary 4:33-47

208. Louis GW, Greenwald-Yarnell M, Phillips RJ, Coolen LM, Lehman MN, Myers MG (2011) Molecular mapping of the neural pathways linking leptin to the neuroendocrine reproductive axis. Endocrinology 152:2302-2310

209. Lungu AO, Zadeh ES, Goodling A, Cochran E, Gorden P (2012) Insulin resistance is a sufficient basis for hyperandrogenism in lipodystrophic women with polycystic ovarian syndrome. J Clin Endocrinol Metab 97:563-567

210. Luo S, Luo J, Cincotta AH (1999) Chronic ventromedial hypothalamic infusion of norepinephrine and serotonin promotes insulin resistance and glucose intolerance. Neuroendocrinology 70:460-465

211. Luo X, Ikeda Y, Parker KL (1994) A cell-specific nuclear receptor is essential for adrenal and gonadal development and sexual differentiation. Cell 77:481-490

212. Luque RM, Kineman RD, Tena-Sempere M (2007) Regulation of hypothalamic expression of KiSS-1 and GPR54 genes by metabolic factors: analyses using mouse models and a cell line. Endocrinology 148:4601-4611

213. Luukkaa V, Pesonen U, Huhtaniemi I, Lehtonen A, Tilvis R, Tuomilehto J, Koulu M, Huupponen R (1998) Inverse correlation between serum testosterone and leptin in men. J Clin Endocrinol Metab 83:3243-3246

214. Macrides F, Bartke A, Dalterio S (1975) Strange females increase plasma testosterone levels in male mice. Science 189:1104-1106

215. Maffei M, Halaas J, Ravussin E, Pratley RE, Lee GH, Zhang Y, Fei H, Kim S, Lallone R, Ranganathan S et al (1995) Leptin levels in human and rodent: measurement of plasma leptin and ob RNA in obese and weight-reduced subjects. Nat Med 1:1155-1161

216. Magiakou MA, Mastorakos G, Webster E, Chrousos GP (1997) The hypothalamic-pituitary-adrenal axis and the female reproductive system. Ann N Y Acad Sci 816:42-56

217. Magni P, Vettor R, Pagano C, Calcagno A, Beretta E, Messi E, Zanisi M, Martini L, Motta M (1999) Expression of a leptin receptor in immortalized gonadotropin-releasing hormonesecreting neurons. Endocrinology 140:1581-1585

218. Maguire M, Lungu A, Gorden P, Cochran E, Stratton P (2012) Pregnancy in a woman with congenital generalized lipodystrophy: leptin's vital role in reproduction. Obstet Gynecol 119:452-455

219. Mahesh VB, Brann DW (2005) Regulatory role of excitatory amino acids in reproduction. Endocrine 28:271-280

220. Mann DR, Plant TM (2002) Leptin and pubertal development. Semin Reprod Med 20:93-102

221. Manning JM, Bronson FH (1989) Effects of prolonged exercise on puberty and luteinizing hormone secretion in female rats. Am J Physiol Regul Integr Comp Physiol 257:R1359-R1364

222. Mantzoros CS, Dunaif A, Flier JS (1997) Leptin concentrations in the polycystic ovary syndrome. J Clin Endocrinol Metab 82:1687-1691

223. Maruniak JA, Bronson FH (1976) Gonadotropic responses of male mice to female urine. Endocrinology 99:963-969

224. Matejek N, Weimann E, Witzel C, Molenkamp G, Schwidergall S, Bohles H (1999) Hypoleptinaemia in patients with anorexia nervosa and in elite gymnasts with anorexia athletica. Int J Sports Med 20:451-456

225. Matsuda J, Yokota I, Iida M, Murakami T, Naito E, Ito M, Shima K, Kuroda Y (1997) Serum leptin concentration in cord 
blood: relationship to birth weight and gender. J Clin Endocrinol Metab 82:1642-1644

226. Mayer C, Boehm U (2011) Female reproductive maturation in the absence of kisspeptin/GPR54 signaling. Nat Neurosci 14(6):704-710

227. Mazen I, El-Gammal M, Abdel-Hamid M, Amr K (2009) A novel homozygous missense mutation of the leptin gene (N103K) in an obese Egyptian patient. Mol Genet Metab 97:305-308

228. Mazen I, El-Gammal M, Abdel-Hamid M, Farooqi IS, Amr K (2011) Homozygosity for a novel missense mutation in the leptin receptor gene (P316T) in two Egyptian cousins with severe early onset obesity. Mol Genet Metab 102:461-464

229. McConway MG, Johnson D, Kelly A, Griffin D, Smith J, Wallace AM (2000) Differences in circulating concentrations of total, free and bound leptin relate to gender and body composition in adult humans. Ann Clin Biochem 37(Pt 5):717-723

230. McDonald JK, Lumpkin MD, DePaolo LV (1989) Neuropeptide-Y suppresses pulsatile secretion of luteinizing hormone in ovariectomized rats: possible site of action. Endocrinology 125:186-191

231. Mercer JG, Hoggard N, Williams LM, Lawrence CB, Hannah LT, Trayhurn P (1996) Localization of leptin receptor mRNA and the long form splice variant $(\mathrm{Ob}-\mathrm{Rb})$ in mouse hypothalamus and adjacent brain regions by in situ hybridization. FEBS Lett 387:113-116

232. Mercer JG, Moar KM, Hoggard N (1998) Localization of leptin receptor $(\mathrm{Ob}-\mathrm{R})$ messenger ribonucleic acid in the rodent hindbrain. Endocrinology 139:29-34

233. Merchenthaler I, Lane MV, Numan S, Dellovade TL (2004) Distribution of estrogen receptor alpha and beta in the mouse central nervous system: in vivo autoradiographic and immunocytochemical analyses. J Comp Neurol 473:270-291

234. Miller KK, Parulekar MS, Schoenfeld E, Anderson E, Hubbard J, Klibanski A, Grinspoon SK (1998) Decreased leptin levels in normal weight women with hypothalamic amenorrhea: the effects of body composition and nutritional intake. J Clin Endocrinol Metab 83:2309-2312

235. Mizuno TM, Mobbs CV (1999) Hypothalamic agouti-related protein messenger ribonucleic acid is inhibited by leptin and stimulated by fasting. Endocrinology 140:814-817

236. Morelli A, Fibbi B, Marini M, Silvestrini E, De Vita G, Chavalmane AK, Vignozzi L, Filippi S, Forti G, Vannelli GB, Maggi M (2009) Dihydrotestosterone and leptin regulate gonadotropin-releasing hormone $(\mathrm{GnRH})$ expression and secretion in human GnRH-secreting neuroblasts. J Sex Med 6:397-407

237. Mori H, Inoki K, Münzberg H, Opland D, Faouzi M, Villanueva EC, Ikenoue T, Kwiatkowski D, MacDougald OA, Myers MG Jr, Guan K-L (2009) Critical role for hypothalamic mTOR activity in energy balance. Cell Metab 9:362-374

238. Moschos S, Chan JL, Mantzoros CS (2002) Leptin and reproduction: a review. Fertil Steril 77:433-444

239. Mounzih K, Lu R, Chehab FF (1997) Leptin treatment rescues the sterility of genetically obese $o b / o b$ males. Endocrinology 138:1190-1193

240. Muraoka O, Xu B, Tsurumaki T, Akira S, Yamaguchi T, Higuchi H (2003) Leptin-induced transactivation of NPY gene promoter mediated by JAK1, JAK2 and STAT3 in the neural cell lines. Neurochem Int 42:591-601

241. Murray PG, Read A, Banerjee I, Whatmore AJ, Pritchard LE, Davies RA, Brennand J, White A, Ross RJ, Clayton PE (2011) Reduced appetite and body mass index with delayed puberty in a mother and son: association with a rare novel sequence variant in the leptin gene. Eur J Endocrinol 164:521-527

242. Myers MG Jr, Münzberg H, Leinninger GM, Leshan RL (2009) The geometry of leptin action in the brain: more complicated than a simple ARC. Cell Metab 9:117-123
243. Myers MG Jr (2004) Leptin receptor signaling and the regulation of mammalian physiology. Recent Prog Horm Res 59:287-304

244. Nagatani S, Guthikonda P, Foster DL (2000) Appearance of a nocturnal peak of leptin secretion in the pubertal rat. Horm Behav 37:345-352

245. Nagatani S, Guthikonda P, Thompson RC, Tsukamura H, Maeda KI, Foster DL (1998) Evidence for GnRH regulation by leptin: leptin administration prevents reduced pulsatile $\mathrm{LH}$ secretion during fasting. Neuroendocrinology 67:370-376

246. Nagatani S, Thompson RC, Foster DL (2001) Prevention of glucoprivic stimulation of corticosterone secretion by leptin does not restore high frequency luteinizing hormone pulses in rats. J Neuroendocrinol 13:371-377

247. Navarro VM, Fernandez-Fernandez R, Castellano JM, Roa J, Mayen A, Barreiro ML, Gaytan F, Aguilar E, Pinilla L, Dieguez C, Tena-Sempere M (2004) Advanced vaginal opening and precocious activation of the reproductive axis by KiSS-1 peptide, the endogenous ligand of GPR54. J Physiol 561:379-386

248. Niijima A, Rohner-Jeanrenaud F, Jeanrenaud B (1984) Role of ventromedial hypothalamus on sympathetic efferents of brown adipose tissue. Am J Physiol 247:R650-R654

249. Niswender KD, Morrison CD, Clegg DJ, Olson R, Baskin DG, Myers MG Jr, Seeley RJ, Schwartz MW (2003) Insulin activation of phosphatidylinositol 3-kinase in the hypothalamic arcuate nucleus: a key mediator of insulin-induced anorexia. Diabetes 52:227-231

250. Niswender KD, Morton GJ, Stearns WH, Rhodes CJ, Myers MG Jr, Schwartz MW (2001) Intracellular signalling. Key enzyme in leptin-induced anorexia. Nature 413:794-795

251. Oakley AE, Clifton DK, Steiner RA (2009) Kisspeptin signaling in the brain. Endocr Rev 30:713-743

252. Ollmann MM, Wilson BD, Yang YK, Kerns JA, Chen Y, Gantz I, Barsh GS (1997) Antagonism of central melanocortin receptors in vitro and in vivo by agouti-related protein [published erratum appears in Science 1998 Sep 11;281(5383):1615]. Science 278:135-138

253. Ostlund RE Jr, Yang JW, Klein S, Gingerich R (1996) Relation between plasma leptin concentration and body fat, gender, diet, age, and metabolic covariates. J Clin Endocrinol Metab 81:3909-3913

254. Otvos L Jr, Kovalszky I, Riolfi M, Ferla R, Olah J, Sztodola A, Nama K, Molino A, Piubello Q, Wade JD, Surmacz E (2011) Efficacy of a leptin receptor antagonist peptide in a mouse model of triple-negative breast cancer. Eur J Cancer 47:15781584

255. Ozata M, Ozdemir IC, Licinio J (1999) Human leptin deficiency caused by a missense mutation: multiple endocrine defects, decreased sympathetic tone, and immune system dysfunction indicate new targets for leptin action, greater central than peripheral resistance to the effects of leptin, and spontaneous correction of leptin-mediated defects. J Clin Endocrinol Metab 84:3686-3695

256. Pardini AW, Nguyen HT, Figlewicz DP, Baskin DG, Williams DL, Kim F, Schwartz MW (2006) Distribution of insulin receptor substrate-2 in brain areas involved in energy homeostasis. Brain Res 1112:169-178

257. Parent AS, Lebrethon MC, Gerard A, Vandersmissen E, Bourguignon JP (2000) Leptin effects on pulsatile gonadotropin releasing hormone secretion from the adult rat hypothalamus and interaction with cocaine and amphetamine regulated transcript peptide and neuropeptide Y. Regul Pept 92:17-24

258. Parfitt DB, Church KR, Cameron JL (1991) Restoration of pulsatile luteinizing hormone secretion after fasting in rhesus monkeys (Macaca mulatta): dependence on size of the refeed meal. Endocrinology 129:749-756 
259. Paz-Filho G, Mastronardi C, Delibasi T, Wong ML, Licinio J (2010) Congenital leptin deficiency: diagnosis and effects of leptin replacement therapy. Arq Bras Endocrinol Metabol 54:690-697

260. Pierroz DD, Catzeflis C, Aebi AC, Rivier JE, Aubert ML (1996) Chronic administration of neuropeptide $\mathrm{Y}$ into the lateral ventricle inhibits both the pituitary-testicular axis and growth hormone and insulin-like growth factor I secretion in intact adult male rats. Endocrinology 137:3-12

261. Pirwany IR, Fleming R, Sattar N, Greer IA, Wallace AM (2001) Circulating leptin concentrations and ovarian function in polycystic ovary syndrome. Eur J Endocrinol 145:289-294

262. Plant TM, Barker-Gibb ML (2004) Neurobiological mechanisms of puberty in higher primates. Hum Reprod Update 10:67-77

263. Popa SM, Clifton DK, Steiner RA (2008) The role of kisspeptins and GPR54 in the neuroendocrine regulation of reproduction. Annu Rev Physiol 70:213

264. Purvis K, Haynes NB (1978) Effect of the odour of female rat urine on plasma testosterone concentrations in male rats. J Reprod Fertil 53:63-65

265. Qiu J, Fang Y, Bosch MA, Ronnekleiv OK, Kelly MJ (2011) Guinea pig kisspeptin neurons are depolarized by leptin via activation of TRPC channels. Endocrinology 152:1503-1514

266. Qiu J, Ogus S, Mounzih K, Ewart-Toland A, Chehab FF (2001) Leptin-deficient mice backcrossed to the BALB/cJ genetic background have reduced adiposity, enhanced fertility, normal body temperature, and severe diabetes. Endocrinology 142:3421-3425

267. Qu D, Ludwig DS, Gammeltoft S, Piper M, Pelleymounter MA, Cullen MJ, Mathes WF, Przypek R, Kanarek R, Maratos-Flier E (1996) A role for melanin-concentrating hormone in the central regulation of feeding behaviour. Nature 380:243-247

268. Quennell JH, Howell CS, Roa J, Augustine RA, Grattan DR, Anderson GM (2011) Leptin deficiency and diet-induced obesity reduce hypothalamic kisspeptin expression in mice. Endocrinology 152(4):1541-1550

269. Quennell JH, Mulligan AC, Tups A, Liu X, Phipps SJ, Kemp CJ, Herbison AE, Grattan DR, Anderson GM (2009) Leptin indirectly regulates gonadotropin-releasing hormone neuronal function. Endocrinology 150:2805-2812

270. Reznikov AG, McCann SM (1993) Effects of neuropeptide Y on gonadotropin and prolactin release in normal, castrated or flutamide-treated male rats. Neuroendocrinology 57:1148-1154

271. Riad-Gabriel MG, Jinagouda SD, Sharma A, Boyadjian R, Saad MF (1998) Changes in plasma leptin during the menstrual cycle. Eur J Endocrinol 139:528-531

272. Roa J, Garcia-Galiano D, Castellano JM, Gaytan F, Pinilla L, Tena-Sempere M (2010) Metabolic control of puberty onset: new players, new mechanisms. Mol Cell Endocrinol 324:87-94

273. Roa J, Garcia-Galiano D, Varela L, Sanchez-Garrido MA, Pineda R, Castellano JM, Ruiz-Pino F, Romero M, Aguilar E, Lopez M, Gaytan F, Dieguez C, Pinilla L, Tena-Sempere M (2009) The mammalian target of rapamycin as novel central regulator of puberty onset via modulation of hypothalamic Kiss1 system. Endocrinology 150:5016-5026

274. Roa J, Tena-Sempere M (2010) Energy balance and puberty onset: emerging role of central mTOR signaling. Trends Endocrinol Metab 21:519-528

275. Rondini TA, Baddini SP, Sousa LF, Bittencourt JC, Elias CF (2004) Hypothalamic cocaine- and amphetamine-regulated transcript neurons project to areas expressing gonadotropin releasing hormone immunoreactivity and to the anteroventral periventricular nucleus in male and female rats. Neuroscience 125:735-748

276. Rouru J, Anttila L, Koskinen P, Penttila TA, Irjala K, Huupponen R, Koulu M (1997) Serum leptin concentrations in women with polycystic ovary syndrome. J Clin Endocrinol Metab 82:1697-1700

277. Routh VH (2003) Glucosensing neurons in the ventromedial hypothalamic nucleus (VMN) and hypoglycemia-associated autonomic failure (HAAF). Diabetes Metab Res Rev 19:348-356

278. Sabatino FD, Collins P, McDonald JK (1989) Neuropeptide-Y stimulation of luteinizing hormone-releasing hormone secretion from the median eminence in vitro by estrogen-dependent and extracellular $\mathrm{Ca} 2+$-independent mechanisms. Endocrinology 124:2089-2098

279. Sadagurski M, Leshan RL, Patterson C, Rozzo A, Kuznetsova A, Skorupski J, Jones JC, Depinho RA, Myers MG Jr, White MF (2012) IRS2 signaling in LepR-b neurons suppresses FoxO1 to control energy balance independently of leptin action. Cell Metab 15:703-712

280. Sadovsky Y, Crawford PA, Woodson KG, Polish JA, Clements MA, Tourtellotte LM, Simburger K, Milbrandt J (1995) Mice deficient in the orphan receptor steroidogenic factor 1 lack adrenal glands and gonads but express $\mathrm{P} 450$ side-chain-cleavage enzyme in the placenta and have normal embryonic serum levels of corticosteroids. Proc Natl Acad Sci USA 92:10939-10943

281. Sawchenko PE (1987) Evidence for differential regulation of corticotropin-releasing factor and vasopressin immunoreactivities in parvocellular neurosecretory and autonomic-related projections of the paraventricular nucleus. Brain Res 437:253-263

282. Sawchenko PE, Brown ER, Chan RK, Ericsson A, Li HY, Roland BL, Kovacs KJ (1996) The paraventricular nucleus of the hypothalamus and the functional neuroanatomy of visceromotor responses to stress. Prog Brain Res 107:201-222

283. Sawchenko PE, Swanson LW (1982) Immunohistochemical identification of neurons in the paraventricular nucleus of the hypothalamus that project to the medulla or to the spinal cord in the rat. J Comp Neurol 205:260-272

284. Sawchenko PE, Swanson LW, Vale WW (1984) Corticotropinreleasing factor: co-expression within distinct subsets of oxytocin-, vasopressin-, and neurotensin-immunoreactive neurons in the hypothalamus of the male rat. J Neurosci 4:1118-1129

285. Scalia F, Winans SS (1975) The differential projections of the olfactory bulb and accessory olfactory bulb in mammals. J Comp Neurol 161:31-55

286. Schioth HB, Kakizaki Y, Kohsaka A, Suda T, Watanobe H (2001) Agouti-related peptide prevents steroid-induced luteinizing hormone and prolactin surges in female rats. NeuroReport 12:687-690

287. Schmelzle T, Hall MN (2000) TOR, a central controller of cell growth. Cell 103:253-262

288. Schneider JE (2004) Energy balance and reproduction. Physiol Behav 81:289-317

289. Schubring C, Englaro P, Siebler T, Blum WF, Demirakca T, Kratzsch J, Kiess W (1998) Longitudinal analysis of maternal serum leptin levels during pregnancy, at birth and up to six weeks after birth: relation to body mass index, skinfolds, sex steroids and umbilical cord blood leptin levels. Horm Res 50:276-283

290. Schwartz MW, Porte DJ (2005) Diabetes, obesity, and the brain. Science 307:375-379

291. Schwartz MW, Seeley RJ, Campfield LA, Burn P, Baskin DG (1996) Identification of targets of leptin action in rat hypothalamus. J Clin Invest 98:1101-1106

292. Schwartz MW, Woods SC, Porte D Jr, Seeley RJ, Baskin DG (2000) Central nervous system control of food intake. Nature 404:661-671

293. Scimonelli T, Celis ME (1990) A central action of alpha-melanocyte-stimulating hormone on serum levels of $\mathrm{LH}$ and prolactin in rats. $\mathrm{J}$ Endocrinol 124:127-132 
294. Scott MM, Lachey JL, Sternson SM, Lee CE, Elias CF, Friedman JM, Elmquist JK (2009) Leptin targets in the mouse brain. J Comp Neurol 514:518-532

295. Screaton RA, Conkright MD, Katoh Y, Best JL, Canettieri G, Jeffries S, Guzman E, Niessen S, Yates Iii JR, Takemori H, Okamoto M, Montminy M (2004) The CREB coactivator TORC2 functions as a calcium- and cAMP-sensitive coincidence detector. Cell 119:61-74

296. Segal JP, Stallings NR, Lee CE, Zhao L, Socci N, Viale A, Harris TM, Soares MB, Childs G, Elmquist JK, Parker KL, Friedman JM (2005) Use of laser-capture microdissection for the identification of marker genes for the ventromedial hypothalamic nucleus. J Neurosci 25:4181-4188

297. Seminara SB, Messager S, Chatzidaki EE, Thresher RR, Acierno JS Jr, Shagoury JK, Bo-Abbas Y, Kuohung W, Schwinof KM, Hendrick AG, Zahn D, Dixon J, Kaiser UB, Slaugenhaupt SA, Gusella JF, O'Rahilly S, Carlton MB, Crowley WF Jr, Aparicio SA, Colledge WH (2003) The GPR54 gene as a regulator of puberty. N Engl J Med 349:1614-1627

298. Sepilian VP, Crochet JR, Nagamani M (2006) Serum soluble leptin receptor levels and free leptin index in women with polycystic ovary syndrome: relationship to insulin resistance and androgens. Fertil Steril 85:1441-1447

299. Shah OJ, Wang Z, Hunter T (2004) Inappropriate activation of the TSC/Rheb/mTOR/S6K cassette induces IRS1/2 depletion, insulin resistance, and cell survival deficiencies. Curr Biol 14:1650-1656

300. Shahab M, Mastronardi C, Seminara SB, Crowley WF, Ojeda SR, Plant TM (2005) Increased hypothalamic GPR54 signaling: a potential mechanism for initiation of puberty in primates. Proc Natl Acad Sci USA 102:2129-2134

301. Shimizu H, Oh IS, Okada S, Mori M (2007) Leptin resistance and obesity. Endocr J 54:17-26

302. Shinoda K, Lei H, Yoshii H, Nomura M, Nagano M, Shiba H, Sasaki H, Osawa Y, Ninomiya Y, Niwa O et al (1995) Developmental defects of the ventromedial hypothalamic nucleus and pituitary gonadotroph in the Ftz-F1 disrupted mice. Dev Dyn Off Publ Am Assoc Anat 204:22-29

303. Shpilman M, Niv-Spector L, Katz M, Varol C, Solomon G, Ayalon-Soffer M, Boder E, Halpern Z, Elinav E, Gertler A (2011) Development and characterization of high affinity leptins and leptin antagonists. J Biol Chem 286:4429-4442

304. Simerly RB (1990) Hormonal control of neuropeptide gene expression in sexually dimorphic olfactory pathways. Trends Neurosci 13:104-110

305. Simerly RB, Chang C, Muramatsu M, Swanson LW (1990) Distribution of androgen and estrogen receptor mRNA-containing cells in the rat brain: an in situ hybridization study. J Comp Neurol 294:76-95

306. Smith JT, Acohido BV, Clifton DK, Steiner RA (2006) KiSS-1 neurones are direct targets for leptin in the $o b / o b$ mouse. J Neuroendocrinol 18:298-303

307. Smith M (1993) Lactation alters neuropeptide-Y and proopiomelanocortin gene expression in the arcuate nucleus of the rat. Endocrinology 133:1258-1265

308. Song Z, Levin BE, McArdle JJ, Bakhos N, Routh VH (2001) Convergence of pre- and postsynaptic influences on glucosensing neurons in the ventromedial hypothalamic nucleus. Diabetes 50:2673-2681

309. Spanswick D, Smith MA, Groppi VE, Logan SD, Ashford ML (1997) Leptin inhibits hypothalamic neurons by activation of ATP-sensitive potassium channels. Nature 390:521-525

310. Spanswick D, Smith MA, Mirshamsi S, Routh VH, Ashford ML (2000) Insulin activates ATP-sensitive K+ channels in hypothalamic neurons of lean, but not obese rats. Nat Neurosci 3:757-758
311. Stanley SA, Small CJ, Kim MS, Heath MM, Seal LJ, Russell SH, Ghatei MA, Bloom SR (1999) Agouti related peptide (Agrp) stimulates the hypothalamo pituitary gonadal axis in vivo $\&$ in vitro in male rats. Endocrinology 140:5459-5462

312. Stratakis CA, Chrousos GP (1995) Neuroendocrinology and pathophysiology of the stress system. Ann N Y Acad Sci $771: 1-18$

313. Sullivan SD, DeFazio RA, Moenter SM (2003) Metabolic regulation of fertility through presynaptic and postsynaptic signaling to gonadotropin-releasing hormone neurons. J Neurosci 23:8578-8585

314. Suter KJ, Pohl CR, Wilson ME (2000) Circulating concentrations of nocturnal leptin, growth hormone, and insulin-like growth factor-I increase before the onset of puberty in agonadal male monkeys: potential signals for the initiation of puberty. J Clin Endocrinol Metab 85:808-814

315. Swain JE, Dunn RL, McConnell D, Gonzalez-Martinez J, Smith GD (2004) Direct effects of leptin on mouse reproductive function: regulation of follicular, oocyte, and embryo development. Biol Reprod 71:1446-1452

316. Swanson LW, Sawchenko PE (1983) Hypothalamic integration: organization of the paraventricular and supraoptic nuclei. Annu Rev Neurosci 6:269-324

317. Swerdloff RS, Batt RA, Bray GA (1976) Reproductive hormonal function in the genetically obese $(o b / o b)$ mouse. Endocrinology 98:1359-1364

318. Tartaglia LA, Dembski M, Weng X, Deng N, Culpepper J, Devos R, Richards GJ, Campfield LA, Clark FT, Deeds J et al (1995) Identification and expression cloning of a leptin receptor, OB-R. Cell 83:1263-1271

319. Tena-Sempere M (2006) The roles of kisspeptins and G proteincoupled receptor-54 in pubertal development. Curr Opin Pediatr $18: 442-447$

320. Tena-Sempere $M$ (2010) Kisspeptin signaling in the brain: recent developments and future challenges. Mol Cell Endocrinol 314:164-169

321. Tena-Sempere M, Barreiro ML (2002) Leptin in male reproduction: the testis paradigm. Mol Cell Endocrinol 188:9-13

322. Terasawa E, Kurian JR, Keen KL, Shiel NA, Colman RJ, Capuano SV (2012) Body weight impact on puberty: effects of high-calorie diet on puberty onset in female rhesus monkeys. Endocrinology 153(4):1696-1705

323. Topaloglu AK, Tello JA, Kotan LD, Ozbek MN, Yilmaz MB, Erdogan S, Gurbuz F, Temiz F, Millar RP, Yuksel B (2012) Inactivating KISS1 mutation and hypogonadotropic hypogonadism. N Engl J Med 366:629-635

324. True C, Kirigiti MA, Kievit P, Grove KL, Smith MS (2011) Leptin is not the critical signal for kisspeptin or luteinising hormone restoration during exit from negative energy balance. J Neuroendocrinol 23:1099-1112

325. Tsukahara S, Tsukamura H, Foster DL, Maeda KI (1999) Effect of corticotropin-releasing hormone antagonist on oestrogendependent glucoprivic suppression of luteinizing hormone secretion in female rats. J Neuroendocrinol 11:101-105

326. Uehara Y, Shimizu H, Ohtani K, Sato N, Mori M (1998) Hypothalamic corticotropin-releasing hormone is a mediator of the anorexigenic effect of leptin. Diabetes 47:890-893

327. Ueno M, Carvalheira J, Tambascia R, Bezerra R, Amaral M, Carneiro E, Folli F, Franchini K, Saad M (2005) Regulation of insulin signalling by hyperinsulinaemia: role of IRS-1/2 serine phosphorylation and the mTOR/p70 S6K pathway. Diabetologia 48:506-518

328. Um SH, Frigerio F, Watanabe M, Picard F, Joaquin M, Sticker M, Fumagalli S, Allegrini PR, Kozma SC, Auwerx J, Thomas G (2004) Absence of S6K1 protects against age- and diet-induced obesity while enhancing insulin sensitivity. Nature 431:200-205 
329. Urban JH, Das I, Levine JE (1996) Steroid modulation of neuropeptide Y-induced luteinizing hormone releasing hormone release from median eminence fragments from male rats. Neuroendocrinology 63:112-119

330. van de Wall E, Leshan R, Xu AW, Balthasar N, Coppari R, Liu SM, Jo YH, MacKenzie RG, Allison DB, Dun NJ, Elmquist J, Lowell BB, Barsh GS, de Luca C, Myers MG Jr, Schwartz GJ, Chua SC Jr (2007) Collective and individual functions of leptin receptor modulated neurons controlling metabolism and ingestion. Endocrinology 149:1773-1785

331. Vanhaesebroeck B, Ali K, Bilancio A, Geering B, Foukas LC (2005) Signalling by PI3K isoforms: insights from gene-targeted mice. Trends Biochem Sci 30:194-204

332. Vantyghem MC, Vincent-Desplanques D, Defrance-Faivre F, Capeau J, Fermon C, Valat AS, Lascols O, Hecart AC, Pigny P, Delemer B, Vigouroux C, Wemeau JL (2008) Fertility and obstetrical complications in women with LMNA-related familial partial lipodystrophy. J Clin Endocrinol Metab 93:2223-2229

333. Vulliemoz NR, Xiao E, Xia-Zhang L, Wardlaw SL, Ferin M (2005) Central infusion of agouti-related peptide suppresses pulsatile luteinizing hormone release in the ovariectomized rhesus monkey. Endocrinology 146:784-789

334. Wade GN, Lempicki RL, Panicker AK, Frisbee RM, Blaustein JD (1997) Leptin facilitates and inhibits sexual behavior in female hamsters. Am J Physiol Regul Integr Comp Physiol 272:R1354-R1358

335. Warren MP, Voussoughian F, Geer EB, Hyle EP, Adberg CL, Ramos RH (1999) Functional hypothalamic amenorrhea: hypoleptinemia and disordered eating. J Clin Endocrinol Metab 84:873-877

336. Watanobe H, Schiöth HB, Wikberg JES, Suda T (1999) The melanocortin 4 receptor mediates leptin stimulation of luteinizing hormone and prolactin surges in steroid-primed ovariectomized rats. Biochem Biophys Res Commun 257:860-864

337. Watanobe H, Suda T, Wikberg JE, Schioth HB (1999) Evidence that physiological levels of circulating leptin exert a stimulatory effect on luteinizing hormone and prolactin surges in rats. Biochem Biophys Res Commun 263:162-165

338. Weidenfeld J, Corcos AP, Wohlman A, Feldman S (1994) Characterization of the 2-deoxyglucose effect on the adrenocortical axis. Endocrinology 134:1924-1931

339. Weigle DS, Duell PB, Connor WE, Steiner RA, Soules MR, Kuijper JL (1997) Effect of fasting, refeeding, and dietary fat restriction on plasma leptin levels. J Clin Endocrinol Metab $82: 561-565$

340. Weimann E, Blum WF, Witzel C, Schwidergall S, Bohles HJ (1999) Hypoleptinemia in female and male elite gymnasts. Eur J Clin Invest 29:853-860

341. Welt CK, Chan JL, Bullen J, Murphy R, Smith P, DePaoli AM, Karalis A, Mantzoros CS (2004) Recombinant human leptin in women with hypothalamic amenorrhea. N Engl J Med 351:987-997

342. White MF (2002) IRS proteins and the common path to diabetes. Am J Physiol Endocrinol Metab 283:E413-E422

343. Williams KW, Margatho LO, Lee CE, Choi M, Lee S, Scott MM, Elias CF, Elmquist JK (2010) Segregation of acute leptin and insulin effects in distinct populations of arcuate proopiomelanocortin neurons. J Neurosci 30:2472-2479

344. Williams KW, Scott MM, Elmquist JK (2011) Modulation of the central melanocortin system by leptin, insulin, and serotonin: co-ordinated actions in a dispersed neuronal network. Eur $\mathrm{J}$ Pharmacol 660:2-12

345. Williams KW, Sohn JW, Donato J Jr, Lee CE, Zhao JJ, Elmquist JK, Elias CF (2011) The acute effects of leptin require PI3K signaling in the hypothalamic ventral premammillary nucleus. J Neurosci 31:13147-13156
346. Wójcik-Gładysz A, Polkowska J (2006) Neuropeptide Y-a neuromodulatory link between nutrition and reproduction at the central nervous system level. Reprod Biol 6:21-28

347. Wójcik-Gladysz A, Wankowska M, Misztal T, Romanowicz K, Polkowska J (2009) Effect of intracerebroventricular infusion of leptin on the secretory activity of the GnRH/LH axis in fasted prepubertal lambs. Anim Reprod Sci 114:370-383

348. Woods SC, D'Alessio DA (2008) Central control of body weight and appetite. J Clin Endocrinol Metab 93:s37-s50

349. Woods SC, Seeley RJ, Porte D Jr, Schwartz MW (1998) Signals that regulate food intake and energy homeostasis. Science 280:1378-1383

350. Wu Q, Palmiter RD (2011) GABAergic signaling by AgRP neurons prevents anorexia via a melanocortin-independent mechanism. Eur J Pharmacol 660:21-27

351. Wu Q, Whiddon BB, Palmiter RD (2012) Ablation of neurons expressing agouti-related protein, but not melanin concentrating hormone, in leptin-deficient mice restores metabolic functions and fertility. Proc Natl Acad Sci USA 109:3155-3160

352. Xu A, Kaelin CB, Takeda K, Akira S, Schwartz MW, Barsh GS (2005) PI3K integrates the action of insulin and leptin on hypothalamic neurons. J Clin Invest 115:951-958

353. Xu B, Sahu A, Crowley WR, Leranth C, Horvath T, Kalra SP (1993) Role of neuropeptide-Y in episodic luteinizing hormone release in ovariectomized rats: an excitatory component and opioid involvement. Endocrinology 133:747-754

354. Yamaoka K, Saharinen P, Pesu M, Holt VE 3rd, Silvennoinen O, O'Shea JJ (2004) The Janus kinases (Jaks). Genome Biol 5:253

355. Yeo G, Farooqi I, Aminian S, Halsall D, Stanhope R, O'Rahilly S (1998) A frameshift mutation in MC4R associated with dominantly inherited human obesity. Nat Genet 20(2):111-112

356. Yokosuka M, Matsuoka M, Ohtani-Kaneko R, Iigo M, Hara M, Hirata K, Ichikawa M (1999) Female-soiled bedding induced fos immunoreactivity in the ventral part of the premammillary nucleus (PMv) of the male mouse. Physiol Behav 68:257-261

357. Yoon H, Enquist LW, Dulac C (2005) Olfactory inputs to hypothalamic neurons controlling reproduction and fertility. Cell 123:669-682

358. Yu WH, Kimura M, Walczewska A, Karanth S, McCann SM (1997) Role of leptin in hypothalamic-pituitary function [published erratum appears in Proc Natl Acad Sci USA 1997 Sep 30;94(20):11108]. Proc Natl Acad Sci USA 94:1023-1028

359. Yu WH, Walczewska A, Karanth S, McCann SM (1997) Nitric oxide mediates leptin-induced luteinizing hormone-releasing hormone (LHRH) and LHRH and leptin-induced LH release from the pituitary gland. Endocrinology 138:5055-5058

360. Yura S, Ogawa Y, Sagawa N, Masuzaki H, Itoh H, Ebihara K, Aizawa-Abe M, Fujii S, Nakao K (2000) Accelerated puberty and late-onset hypothalamic hypogonadism in female transgenic skinny mice overexpressing leptin. J Clin Invest 105:749-755

361. Zamorano PL, Mahesh VB, De Sevilla LM, Chorich LP, Bhat GK, Brann DW (1997) Expression and localization of the leptin receptor in endocrine and neuroendocrine tissues of the rat. Neuroendocrinology 65:223-228

362. Zhang Y, Proenca R, Maffei M, Barone M, Leopold L, Friedman JM (1994) Positional cloning of the mouse obese gene and its human homologue [published erratum appears in Nature 1995 Mar 30;374(6521):479] [see comments]. Nature 372:425-432

363. Zhao AZ, Huan JN, Gupta S, Pal R, Sahu A (2002) A phosphatidylinositol 3-kinase phosphodiesterase 3B-cyclic AMP pathway in hypothalamic action of leptin on feeding. Nat Neurosci 5:727-728

364. Zigman JM, Jones JE, Lee CE, Saper CB, Elmquist JK (2006) Expression of ghrelin receptor mRNA in the rat and the mouse brain. J Comp Neurol 494:528-548 